\title{
Progress in Evaluation of Radionuclide Geochemical Information Developed by DOE High-Level Nuclear Waste Repository Site Projects: Report for January-March 1985
}
A. D. Kelmers
F. G. Seeley
W. D. Arnold
J. G. Blencoe
R. E. Meyer
G. K. Jacobs
S. K. Whatley

Prepared for the

Division of Waste Management

Office of Nuclear Material Safety and Safeguards

U.S. Nuclear Regulatory Commission

under Interagency Agreement DOE 40-549-75 


\section{NOTICE}

This report was prepared as an account of work sponsored by an agency of the United States Government. Neither the United States Government nor any agency thereof, or any of their employees, makes any warranty, expressed or implied, or assumes any legal liability or responsibility for any third party's use, or the results of such use, of any information, apparatus product or process disclosed in this report, or represents that its use by such third party would not infringe privately owned rights.

Available from

Superintendent of Documents

U.S. Government Printing Office

Post Office Box 37082

Washington, D.C. 20013-7982

and

National Technical Information Service

Springfield, VA 22161 


\section{DISCLAIMER}

Portions of this document may be illegible in electronic image products. Images are produced from the best available original document. 
NUREG/CR-4236, Vo1. 2

ORNL/TM-9614/V2

Dist. Category RW

PROGRESS IN EVALUATION OF RADIONUCLIDE GEOCHEMICAL INFORMATION DEVELOPED BY DOE HIGH-LEVEL NUCLEAR WASTE REPOSITORY SITE PROJECTS: REPORT FOR JANUARY-MARCH 1985

A. D. Kelmers

F. G. Seeley

Chemical Technology Division

W. D. Arnold

J. G. Blencoe

NUREG/CR--4236-Vol . 2

R. E. Meyer

Chemistry Division

G. K. Jacobs

Environmental Sciences Division

S. K. Whatley

Program Manager

Repository Licensing Analysis and Support

Chemical Technology Division

NOTICE This document contains information of a preliminary nature.

It is subject to revision or correction and therefore does not represent a

final report.

Manuscript Completed: June 1985

Date of Issue: September 1985

Prepared for the

Division of Waste Management

Office of Nuclear Material Safety and Safeguards

U.S. Nuclear Regulatory Commission

Washington, DC 20555

under Interagency Agreement DOE 40-549-75

NRC FIN No. B0290

Prepared by the

OAK RIDGE NATIONAL LABORATORY

Oak Ridge, Tennessee 37831

operated by

MARTIN MARIETTA ENERGY SYSTEMS, INC.

for the

U.S. Department of Energy

TI86 001269 


\title{
Previous reports in this series:
}

\author{
October 1982 - September 1983 \\ October 1983 - December 1983 \\ January 1984 - March 1984 \\ April 1984 - June 1984 \\ October 1983 - September 1984 \\ October 1984 - December 1984
}

\author{
NUREG/CR-3730 \\ NUREG/CR-3851, Vo1 . I \\ NUREG/CR-3851, Vo1. 2 \\ NUREG/CR-3851, Vo1. 3 \\ NUREG/CR-4136 \\ NUREG/CR-4236, Vol. 1
}

\section{DISCLAIMER}

This report was prepared as an account of work sponsored by an agency of the United States Government. Neither the United States Government nor any agency thereof, nor any of their employees, makes any warranty, express or implied, or assumes any legal liability or responsibility for the accuracy, completeness, or usefulness of any information, apparatus, product, or process disclosed, or represents that its use would not infringe privately owned rights. Reference herein to any specific commercial product, process, or service by trade name, trademark, manufacturer, or otherwise does not necessarily constitute or imply its endorsement, recommendation, or favoring by the United States Government or any agency thereof. The views and opinions of authors expressed herein do not necessarily state or reflect those of the United States Government or any agency thereof. 
Geochemical information relevant to the retention of radionuclides by the Hanford Site (in basalt) and the Yucca Mountain site (in tuff), candidate high-level nuclear waste geologic repositories being developed by U.S. Department of Energy (DOE) projects, is being evaluated by Oak Ridge National Laboratory (ORNL) for the U.S. Nuclear Regulatory Commission (NRC). Our evaluation of the sorption of technetium by basalt/groundwater systems was essentially completed this quarter and the results summarized; we conclude that the experimental methodology and results reported by the DOE for the Hanford Site have not conclusively established that significant retardation of technetium migration may be provided by phases present in the basalts of the Hanford Site. We have shown that sodium boltwoodite is the saturating uranium solid phase in two basalt/groundwater systems. Because thermodynamic data are not available for sodium boltwoodite, calculated solubilities for uranium are erroneous in these systems. Results of radionuclide solubility/speciation calculations, published by the DOE for the Yucca Mountain site, were evaluated this quarter under our geochemical modeling task. We express concerns relative to the inherent limitations of such calculations. Samples of Yucca Mountain tuff and J-13 wel1 water were recelved for use in our planned radionuclide sorption/solubility experiments. These Yucca Mountain materials will be used to evaluate radionuclide sorption and apparent concentration limit values published by the Nevada Nuclear Waste Storage Investigations (NNWSI) project. 
CONTENTS

$\underline{\text { Page }}$

ABSTRACT iii

PREFACE. . . . . . . . . . . . . . . . . . . vii

1. EXECUTIVE SUMMARY. . . . . . . . . . . . . 1

2. INTRODUCTION .......................... 4

3. MATERIALS AND METHODS. ............... 5

3.1 HANFORD SITE MATERIALS. . . . ......... 5

3.2 YUCCA MOUNTAIN MATERIALS. .............. 5

3.2.1 Tuff Samples................ 5

3.2.1.1 Sample Characterization ........ 5

3.2.1.2 Crushed Sample for Sorption

Experiments ............. 8

3.2.2 Well Water Samples.............. 8

3.2.3 Synthetic J-13 We11 Water............. 11

3.3 BATCH CONTACT METHODOLOGY . . . . . . . . . . . 11

4. TECHNETIUM SORPTION/SOLUBILITY VALUES FOR HANFORD SITE

BASALT/GROUNDWATER SYSTEMS . . . . . . . . . . . . . 13

4.1 PUBLISHED SOLUBILITY AND SORPTION INFORMATION . . . . . 13

4.2 EXPERIMENTAL METHODS AND MATERIALS. . . . . . . . . 13

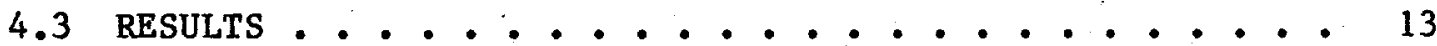

4.3.1 Sorption Isotherms . . . . . . . . . . 13

4.3.2 Effect of Basalt Particle Size . . . . . . . 13

4.4 DISCUSSION. . . . . . . . . . . . 17

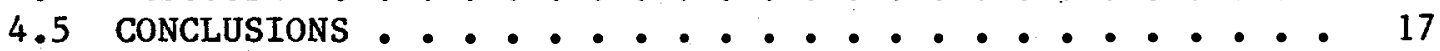

4.6 EVALUATION OF PUBLISHED INFORMATION . . . . . . . 21

5. URANIUM SORPTION/SOLUBILITY VALUES FOR HANFORD SITE

BASALT/GROUNDWATER SYSTEMS . . . . . . . . . . . . . 24

5.1 PUBLISHED SOLUBILITY AND SORPTION INFORMATION. . . . . . 24

5.2 RESULTS. . . . . . . . . . . . . . 24

5.3 DISCUSSION .......................... 26

6. GEOCHEMICAL MODELING-RADIONUCLIDE SOLUBILITY/SPECIATION

INFORMATION RELEVANT TO YUCCA MOUNTAIN . . . . . . . . 28

6.1 PUBLISHED INFORMATION. . . . . . . . . . . 28

6.2 EVALUATION METHODS . . . . . . . . . . . . . . 28

6.3 RESUlTS. . . . . . . . . . . . . . . 30

6.3 .1 Uranlum .................. 30

6.3.2 Strontium .................. 30

6.3.3 Americium ................. 32

6.3 .4 Plutontum . . . . . . . . ...... 33

6.4 DISCUSSION .................. 36

7. ACKNOWLEDGMENTS. . . . . . . . . . . . 37

8. REFERENCES . . . . . . . . . . . 38

$v / \sqrt{1}$ 
This document is the seventh in a series of progress reports that are being issued by the U.S. Nuclear Regulatory Commission to describe the current status of an experimental program to evaluate the radionuclide geochemical information developed by the high-level nuclear waste repository site projects of the U.S. Department of Energy. 
PROGRESS IN EVALUATION OF RADIONUCLIDE GEOCHEMICAL INFORMATION

DEVELOPED BY DOE HIGH-LEVEL NUCLEAR WASTE REPOSITORY

SITE PROJECTS: REPORT FOR JANUARY-MARCH 1985
A. D. Kelmers
F. G. Seeley
W. D. Arnold
J. G. Blencoe
R. E. Meyer
G. K. Jacobs
S. K. What ley

\section{EXECUTIVE SUMMARY}

This project, supported by the U.S. Nuclear Regulatory Commission (NRC), is being conducted to evaluate the radionuclide geochemical information and data acquisition methodology that may be employed by U.S. Department of Energy (DOE) high-level nuclear waste repository site projects in performance assessment calculations to show reasonable assurance of expected compliance with regulatory requirements. This effort focuses on parameters that are important to the mobility of radionuclides in geologic media (primarily, sorption on host rock and apparent concentration limits in groundwater) under the anticipated geochemical conditions of the repository. Initial emphasis was on information being developed by the Basalt Waste Isolation Project (BWIP) that is applicable to the Hanford Site candidate repository in the Columbia River basalts at Richland, Washington. Attention is now being shifted to evaluate information being developed by the Nevada Nuclear Waste Storage Investigations (NNWSI) project that is relevant to the Yucca Mountain site in tuff at the Nevada Test Site, Nevada.

Samples of Yucca Mountain tuff and related groundwater were received from the NNWSI. Core samples of Topopah Spring (the candidate repository hori$z$ on in the unsaturated zone), Calico Hills (the unsaturated zone tuff unit underlying Topopah Spring), and Bullfrog (the first major saturated zone unit) tuffs, as well as an outcrop sample of Topopah Spring tuff from Busted Butte, were received. These samples are being mineralogically characterized to determine: (1) if outcrop material is suitable for use in sorption experiments, and (2) if it is possible to compare mineralogical differences in tuff units with sorption behavior. Samples of J-13 well water (the water used in most of the published sorption experiments) were also received and chemically analyzed. These Yucca Mountain materials will be used in our planned laboratory experiments to evaluate radionuclide sorption and apparent concentration limit values published by the NNWSI. A method of preparing synthetic J-13 well water was also developed. The behavior of radionuclides in actual and synthetic J-13 well water will be studied to determine if the synthetic water is suitable for use in sorption experiments. Use of synthetic water could help alleviate the problems associated with microbiological activity present in actual J-13 well water. 
Al1 current1y planned work to evaluate the sorption/solubility behavior of technetium in basalt/groundwater systems has been completed. The following major conclusions were reached as a result of this work:

1. Significant sorption is not observed under oxic redox conditions.

2. Significant sorption is observed only if the basalt is crushed and stored in an inert atmosphere and stringent precautions are taken to exclude traces of air from the experiment; the test atmosphere must contain <1 ppm oxygen.

3. Sorption isotherms are linear at low technetium concentrations under anoxic redox conditions.

4. Technetium sorption ratios are higher for the Cohassett basalt/ synthetic groundwater GR-4 system than for the McCoy Canyon basalt/synthetic groundwater GR-2 system.

5. The sorption ratios (Rs values) measured are not very sensitive to the particle size of the basalt used in the anoxic redox condition tests. This is in sharp contrast to the results we obtained earlier for neptunium sorption.

6. The solubility limit for reduced technetium species may be lower than the values of $10^{-5}$ to $10^{-6} \mathrm{~mol} / \mathrm{L}$ which we previously reported. This is being explored further in work under a parallel NRC research project.

7. Sorption of pertechnetate clearly involves reduction to a lower valence, but the reactions involved and reaction kinetics are complex and not clearly understood.

We conclude that our evaluation of both the experimental methodology and results reported by the BWIP to date for technetium sorption or solubility limits do not conclusively indicate that significant retardation may be provided by phases present in the basalts at the Hanford Site. Additional consideration of technetium sorption/solubility behavior may be necessary if the Hanford Site performance assessment strategy will give importance to retardation of technetium by site components.

Uranium sorption isotherms were completed for the Cohassett basalt/synthetic groundwater GR-4 system under anoxic redox conditions. As was previously observed with the McCoy Canyon basalt/synthetic groundwater GR-2 system, sodium boltwoodite, $\mathrm{Na}\left(\mathrm{UO}_{2}\right)\left(\mathrm{SiO}_{3}\right)(\mathrm{OH}) \cdot 5 / 2 \mathrm{H}_{2} \mathrm{O}$, is the saturating solid phase. The apparent concentration limit under anoxic conditions was between $10^{-6}$ to $10^{-8} \mathrm{~mol} / \mathrm{L}$. Because thermodynamic data are not available for sodium boltwoodite, geochemical model calculations cannot simulate the precipitation of this phase. Therefore, calculations for oxic conditions will probably overestimate total uranium concentration. Under anoxic conditions, where $\mathrm{UO}_{2}$ or other $U($ IV) phases are thought to control uranium concentration, model calculations may underestimate total uranium concentration. These results illustrate the importance of identifying the solid 
phases present in experimental measurements and some possible limitations associated with the use of incomplete thermodynamic data in geochemical modeling.

Results of radionuclide solubility/speciation calculations, published by the NNWSI relevant to the Yucca Mountain site, were evaluated this quarter under our geochemical modeling task. The calculated solubility/speciation of several radionuclides appears to be reasonable for the assumptions and thermodynamic data used. However, agreement between our results and those published by the NNWSI does little more than verify that the computer code used by NNWSI (EQ3/6) and that used by ORNL (MINTEQ) solve thermodynamic relationships correctly and that the data bases are not inconsistent. Limitations of such calculations include: (1) the assumption of equilibrium, (2) missing or invalid data, (3) incomplete accounting of all geochemical processes, and (4) lack of experimental validation. We are concerned that such calculated solubility information may be difficult to defend as meeting the "reasonable assurance" criteria of 10 CFR Part 60 . 


\section{INTRODUCTION}

The objective of this project is to support the NRC staff analysis of geochemical information used by the DOE to predict the performance of candidate high-level waste geologic repository sites. Under this task, both experimental and calculational activities are undertaken to evaluate pertinent geochemical values and the methodology used in the development of these values. These results are then compared with published information reported by the DOE site projects or others and, where appropriate, concerns are expressed relative to the accuracy, conservatism, or relevance of the information for the prediction of repository performance.

This project is primarily a laboratory activity because it is anticipated that the DOE may rely on experimentally measured apparent concentration limits and sorption distribution coefficients for radionuclides to describe the isolation performance of the site. The experimental methodologies used by the DOE site projects, the selection and characterization of site materials used in the DOE experiments, and the DOE test results are being eva1uated. The appropriateness of the materials selected and methodology employed to simulate repository geochemical conditions is considered. The conservatism inherent in the laboratory approach is being evaluated. In addition, attention is directed toward geochemical modeling efforts, both to support our laboratory work and to evaluate the data bases and calculational methodologies employed in the geochemical modeling used by the DOE. For example, the DOE site projects may elect to calculate some geochemical values, such as radionuclide solubility, without supporting laboratory measurements. The DOE site projects may also use modeling methodology to extrapolate laboratory information to conditions of temperature and chemistry that are unexplored experimentally. These and other aspects of the geochemical methodology and values of the DOE site project will be examined in light of the reasonable assurance criteria of the NRC regulation 10 CFR Part 60 .

During this report period, we have begun shifting programmatic emphasis from evaluation of information relative to the Columbia River basalts at the Hanford Site to information for the Yucca Mountain site at the Nevada Test Site, Nevada, one of the leading candidate repository locations identified by the DOE. Our initial effort will be focused on evaluation of the laboratory sorption methodology used to develop the extensive catalog of sorption (and desorption) information for a number of radionuclides with samples from various tuff units (DANIELS 1982; OGARD 1983; DOE 1984a).

The batch contact methodology used to acquire the Yucca Mountain sorption information must reflect the geochemical conditions within the repository block as well as along possible release pathways. We plan to reevaluate our laboratory methodology, which was developed during our previous work with basalt/groundwater samples, and alter it as necessary in order to maintain relevance of the results to the Yucca Mountain site. As in the past, emphasis will be given to evaluating the behavior of key radionuclides (i.e., those most likely to dominate radioactivity releases and exposure to man). 


\subsection{HANFORD SITE MATERIALS}

The preparation and characterization of the basalt samples and synthetic groundwaters and comparison of the synthetic groundwater formulations used in the sorption experiments have been described previously (KELMERS 1985a).

\subsection{YUCCA MOUNTAIN MATERIALS}

\subsubsection{Tuff Samples}

\subsubsection{Sample Characterization}

Three core samples (Fig. 3.1) from drill hole USW-GI and a sample of Busted Butte outcrop (Fig. 3.2) were recelved from the U.S. Geological Survey, Mercury, Nevada. The source and description of these samples are given in Table 3.1.

Table 3.1 Source and description of Yucca Mountain tuff samples ${ }^{a}$

\begin{tabular}{|c|c|c|c|c|}
\hline Sample & $\begin{array}{l}\text { Weight } \\
\text { (g) }\end{array}$ & Rock unit & $\begin{array}{l}\text { Depth } \\
(\mathrm{ft})\end{array}$ & We11 \\
\hline Core & 1,779 & $\begin{array}{l}\text { Topopah Spring: } \\
\text { 11thophysal }\end{array}$ & $1189.7-1190.3$ & USW-GI \\
\hline Core & 927 & $\begin{array}{l}\text { Topopah Spring: } \\
\text { nonlithophysal }\end{array}$ & $1226.8-1226.9$ & USW-GI \\
\hline Core & 1,767 & $\begin{array}{l}\text { Calico Hills: } \\
\text { lithics in matrix }\end{array}$ & $1474.8-1476.0$ & USW-G1 \\
\hline Core & 1,778 & $\begin{array}{l}\text { Bullfrog: } \\
\text { saturated }\end{array}$ & $2314.4-2315.7$ & USW-GI \\
\hline Outcrop & 14,500 & Topopah Spring & surface & $\begin{array}{l}\text { Busted Butte } \\
\text { outcrop }\end{array}$ \\
\hline
\end{tabular}

a Information supplied by the U.S. Geological Survey, Mercury, Nevada.

The tuff samples are being characterized by petrographic and $x$-ray diffraction (XRD) techniques in order to be able to relate the sorption values measured with sample mineralogy and texture. The samples selected for examination are small chips of outcrop and core material that are superficially similar to one another. Each rock is mottled and buff/brown in color, while the outcrop is somewhat darker than the core material. Both chips contain Iithic fragments that were exposed by sawing in the preparation of the thin 
ORNL-PHOTO 4785-85



Fig. 3.1. Photograph of Yucca Mountain core samples (for description see Table 3.1). 


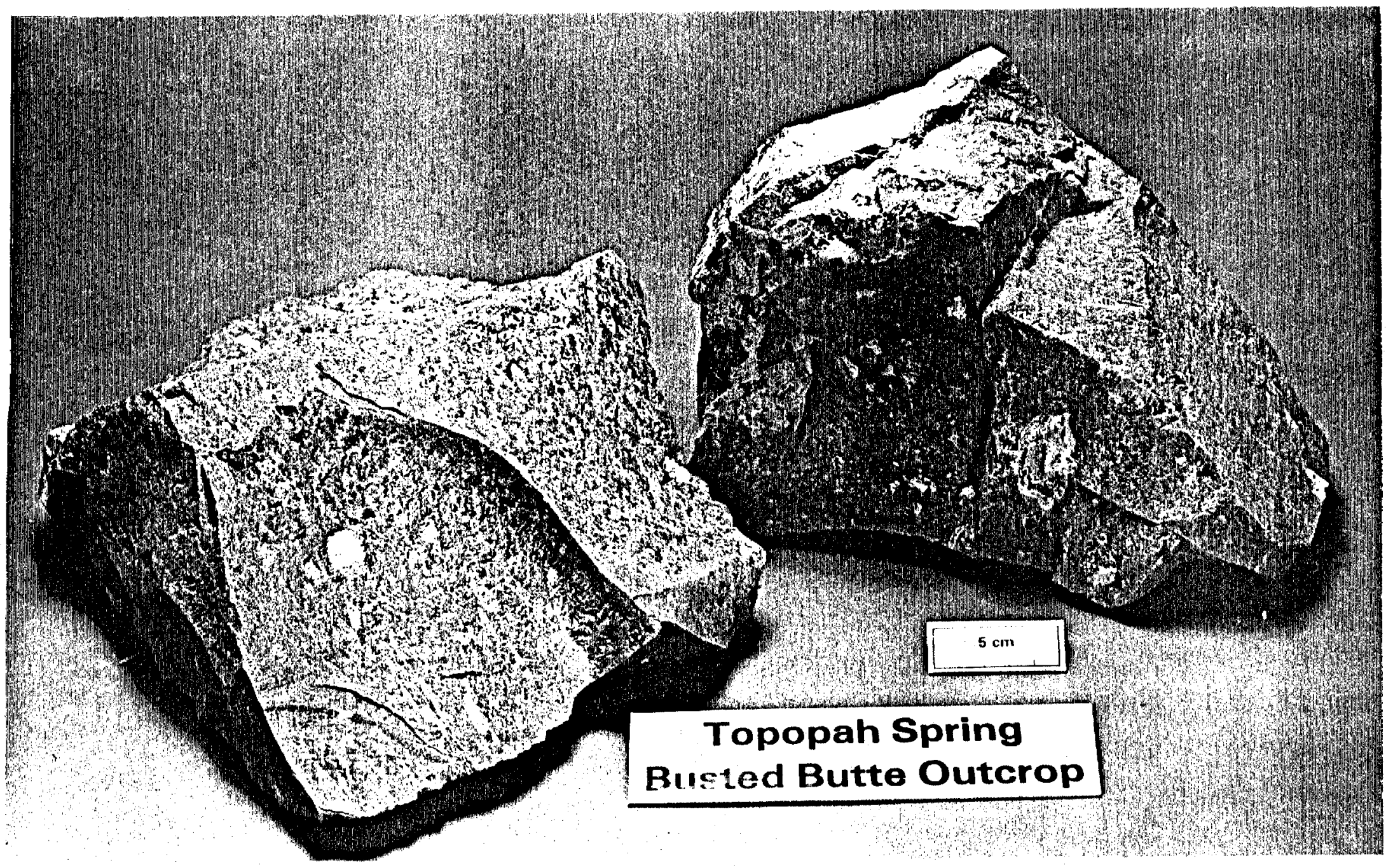

Fig. 3.2. Photograph of Busted Butte outcrop (for description see Table 3.1). 
sections. Mineralogical investigation of these lithic fragments is being emphasized because it appears that many of them have altered rims which, based on previous investigations (BISH 1982, VANIMAN 1984), may consist of clay minerals and zeolites that were produced originally by deuteric alteration. We believe it is possible that the minerals in these alteration rims, as well as other minerals in the outcrop material, may have been affected by weathering, and, thus, could have different sorptive properties than the core material.

Preliminary examinations performed so far indicate that the lithic fragments, reaction rims, and groundmass material in the outcrop and core material may be significantly different mineralogically. We will attempt to quantify these differences when the XRD analyses are completed. The use of outcrop material in tests to predict behavior at depth will also be investigated.

\subsubsection{Crushed Sample for Sorption Experiments}

A 2.4-kg sample of Topopah Spring tuff from the Busted Butte outcrop has been crushed for our initial sorption methodology tests. The procedure used in the preparation of this sample follows.

The total weight of the two rocks of outcrop material received was $\sim 14.5 \mathrm{~kg}$. An $\sim 4-\mathrm{kg}$ portion of the larger of the two rocks was crushed by wrapping the rock in heavy canvas and striking it with a 10-1b sledge hammer. The canvas was used to prevent possible contamination of the material with metal from the sledge hammer. The size was reduced further with a large porcelain mortar and pestle. When all particles passed through a 4-mesh screen, the crushed material was then placed in an automatic Fritsch agate mortar and pestle, and using a relatively short intermittent grinding and screening technique, the particle size was reduced to -70 mesh $(<210 \mu \mathrm{m})$ with a minimum amount of -325 -mesh $(<44-\mu \mathrm{m})$ particles. Approximately $2.4 \mathrm{~kg}$ of material was recovered in this manner. The sieve analysis is shown in Table 3.2 .

\subsubsection{Well Water Samples}

Four gallons of J-13 well water were also received from the U.S. Geological Survey, Mercury, Nevada. The water was shipped in plastic bottles that had been painted to protect the water from light to prevent biogrowth. The bottles had been filled to the rim to eliminate any air space that could allow degassing of dissolved $\mathrm{CO}_{2}$. The analyses for this well water (identified as J-13-2 in Table 3.3) have been completed. The composition compares favorably with Reference $\mathrm{J}-13$ well water analyses (DANIELS 1982) except for a slightly higher concentration of iron $(0.21 \mathrm{vs} 0.04 \mathrm{mg} / \mathrm{L})$. The analyses for another sample of $\mathrm{J}-13$ well water (identified as $\mathrm{J}-13-1$ in Table 3.3) that was received earlier are also included. This earlier sample of well water was collected and shipped in light-transmitting commercial distilled water jugs equipped with snap caps. The jugs had leaked, and there was a considerable amount of air space above the water. 
Table 3.2. Sieve analysis of crushed sample of Busted Butte outcrop

\begin{tabular}{|c|c|c|c|}
\hline $\begin{array}{l}\text { Sieve No. } \\
\text { range }\end{array}$ & $\begin{array}{l}\text { Weight } \\
\text { (g) }\end{array}$ & $\begin{array}{c}\text { Particle-size } \\
\text { range } \\
(\mu \mathrm{m})\end{array}$ & $\begin{array}{l}\text { Percent } \\
\text { of total }\end{array}$ \\
\hline$-70 /+100$ & 564.7 & $\langle 210 /\rangle 149$ & 23.5 \\
\hline$-100 /+170$ & 689.6 & $\langle 149 />88$ & 28.7 \\
\hline$-170 /+200$ & 196.3 & $<88 />63$ & 8.2 \\
\hline$-200 /+325$ & 438.6 & $\langle 63 /\rangle 44$ & 18.3 \\
\hline-325 & 512.7 & $<44$ & 21.3 \\
\hline Total & \multicolumn{2}{|l|}{2401.9} & 100.0 \\
\hline \multicolumn{4}{|c|}{$\begin{array}{l}\text { Analytical samples (which were proportional to the above weight } \\
\text { actions) were obtained from each of the particle-size fractions by } \\
\text { ing a riffle sample splitter. The remainder of the ground fractions } \\
\text { :e combined, mixed for several hours in a V-blender, and then riffled } \\
\text { appropriate size storage samples ( } 50 \text { and } 100 \mathrm{~g} \text { ). }\end{array}$} \\
\hline
\end{tabular}

Although there was some concern about the condition of this sample as received, the analyses also compared favorably with both the J-13 Reference and $J-13-2$ well water analyses.

An interesting observation was made concerning the growth of algae in a sample of J-13 well water that was removed from the stock jug and placed in a window where it could recelve sunlight for several weeks. This behavior was explored because microbiological activity in $\mathrm{J}-13$ wel1 water has been previously reported (BRYANT 1984; WOLFSBERG 1984). The algae first appeared as tiny yellow/buff-colored dots that grew into colonies $\sim 4-10 \mathrm{~mm}$ in diameter. After appearing to attain a maximum size in $\sim 1$ week, the colonies began to break up until the material was deposited as a thin uniform layer on the bottom of the container. In 2 weeks, this layer of material had disappeared, and the solids appeared to have gone back into solution. This whole process spanned a period of 1 month. A second test to grow algae has been initiated. At the time of maximum biological activity, the solution will be analyzed to determine which ions are being used as nutrients and have been removed from the well water solution. This observation emphasized the need to exercise caution in isolating samples of J-13 from light. The growth of microorganisms in the well water could affect radionuclide sorption and/or solubility experimental results as well as alter the well water composition. 
Table 3.3 Analyses of $\mathrm{J}-13$ we11 water

\begin{tabular}{|c|c|c|c|c|c|c|}
\hline \multirow{2}{*}{$\begin{array}{l}\text { Constit- } \\
\text { uent }\end{array}$} & \multicolumn{2}{|c|}{ Reference $\mathrm{J}-13^{\mathrm{a}}$} & \multicolumn{2}{|c|}{$J-13-1$} & \multicolumn{2}{|c|}{$J-13-2$} \\
\hline & $(\mathrm{mg} / \mathrm{L})$ & $(\mathrm{meq} / \mathrm{L})$ & $(\mathrm{mg} / \mathrm{L})$ & $(\operatorname{meq} / \mathrm{L})$ & $(\mathrm{mg} / \mathrm{L})$ & (meq/L) \\
\hline Mg & 2.1 & 0.17 & 2.0 & 0.16 & 1.9 & 0.16 \\
\hline Si & 31. & 4.3 & 30 & 4.3 & 29. & 4.1 \\
\hline $\mathrm{Fe}$ & 0.04 & 0.002 & $<0.03$ & $<0.002$ & 0.21 & 0.01 \\
\hline $\mathrm{Sr}$ & 0.05 & 0.001 & 0.034 & 0.0008 & 0.03 & 0.0007 \\
\hline $\mathrm{Ba}$ & 0.003 & 0.00004 & $<0.02$ & $<0.0003$ & 0.02 & 0.0003 \\
\hline $\begin{array}{l}\mathrm{Ca} \\
\mathrm{Li}\end{array}$ & $\begin{array}{l}14 . \\
0.05\end{array}$ & $\begin{array}{l}0.7 \\
0.007\end{array}$ & $\frac{12}{b}$ & $\begin{array}{c}0.6 \\
b\end{array}$ & $\begin{array}{l}12 . \\
<0.2\end{array}$ & $\begin{array}{c}0.6 \\
<0.03\end{array}$ \\
\hline $\mathrm{K}$ & 4.9 & 0.13 & 4.4 & 0.11 & 4.6 & 0.12 \\
\hline AI & 0.03 & 0.003 & $<0.2$ & $<0.02$ & $<0.2$ & $<0.02$ \\
\hline $\mathrm{Na}$ & 51 & 2.2 & 56. & 2.4 & 52. & 2.3 \\
\hline \multicolumn{2}{|c|}{ Total meq/L } & 7.51 & & 7.57 & & 7.29 \\
\hline & & & Anions & & & \\
\hline $\begin{array}{l}\mathrm{F}^{-} \\
\mathrm{Cl}^{-} \\
\mathrm{PO}_{4}{ }^{3-} \\
\mathrm{NO}_{3}- \\
\mathrm{SO}_{4} 2^{2-} \\
\mathrm{CO}_{3}{ }^{2-} \\
\mathrm{HCO}_{3}-\end{array}$ & $\begin{array}{c}2.2 \\
7.5 \\
0.12 \\
5.6 \\
22 . \\
0.0 \\
120 .\end{array}$ & $\begin{array}{l}0.12 \\
0.21 \\
0.004 \\
0.09 \\
0.46 \\
\quad b \\
1.97 \\
\end{array}$ & $\begin{array}{c}2.0 \\
7.0 \\
<5 . \\
11 . \\
18 . \\
0.0 \\
102 .\end{array}$ & $\begin{array}{c}0.11 \\
0.20 \\
<0.16 \\
0.18 \\
0.36 \\
\mathrm{~b} \\
1.67 \\
\end{array}$ & $\begin{array}{c}2.0 \\
6.0 \\
2.0 \\
9.0 \\
16 . \\
0.0 \\
104 .\end{array}$ & $\begin{array}{l}0.11 \\
0.17 \\
0.06 \\
0.15 \\
0.33 \\
\mathrm{~b} \\
1.70 \\
\end{array}$ \\
\hline Total meq & & 2.85 & & 2.52 & & 2.52 \\
\hline
\end{tabular}

Other analyses

$\begin{array}{rrrr}\mathrm{pH} & 7.1 & 7.4 & 7.3 \\ & \mathrm{~b} & 6.8^{\mathrm{c}} & 6.8^{\mathrm{C}}\end{array}$

aDANIELS 1982. W. R. Danfels et al., Summary Report on the Geochemistry of Yucca Mountain and Environs, LA-9328-MS, Los Alamos National Laboratory, Los Alamos, New Mexico, 1982.

bNot determined.

cThese pH values were obtained immediately upon opening the jugs of well water; the higher $\mathrm{pH}$ values were taken after the samples had been removed and had been exposed to air for $\sim 1$ day. 


\subsubsection{Synthetic J-13 We11 Water}

In order to have a readily available source of J-13 we11 water of consistent composition for use in our radionuclide sorption tests, we investigated the preparation of synthetic J-13 well water. In addition, the microbiological growth that occurs in the $\mathrm{J}-13$ wel1 water may introduce experimental uncertainties in the sorption tests.

We were not able to prepare synthetic $\mathrm{J}-13$ wel1 water by the procedure described by Soo (1984), because we could not dissolve silicic acid in hot $\mathrm{NaHCO}_{3}$ solution as described in the published account. We therefore deve1oped another method for preparing synthetic J-13 wel1 water by making up a series of concentrates and using a sillca-containing solution that we had prepared previously for preparation of synthetic BWIP groundwaters (KELMERS 1985a).

The synthetic J-13 well water was prepared by diluting the concentrates as described in Table 3.4. The $\mathrm{pH}$ of the solution was adjusted from the initial value of 10.7 to 7.0 by bubbling $\mathrm{CO}_{2}$ gas through the solution for a few minutes. Titration with $0.05 \mathrm{M}$ HCl showed that the synthetic well water contained significant concentrations (Table 3.5) of carbonate and hydroxide tons before $\mathrm{pH}$ adjustment and essentially only bicarbonate ion after adjustment. (The solutions also contained dissolved $\mathrm{CO}_{2}$ that was not detected by the titration procedure used). After stirring in air overnight, the $\mathrm{pH}$ of the adjusted solution increased to 8.1. This increase in $\mathrm{pH}$ was presumably caused by loss of dissolved $\mathrm{CO}_{2}$ from the solution. The adjusted solution $\mathrm{pH}$ decreased from 7.0 to 5.0 after overnight storage in a $100 \% \mathrm{CO}_{2}$ atmosphere, and it decreased from 7.0 to 6.4 after overnight storage in a $5 \% \mathrm{CO}_{2}-95 \%$ air mixture. Neither solution was stirred during exposure to these two atmospheres. Similarly, a sample of actual J-13 well water that had been stored for 2.5 months in a closed plastic bottle had a pH of 9.2 after storage, compared to the $\mathrm{pH}$ value of 6.8 when the sample was received and $\mathrm{a} \mathrm{pH}$ of 7.3 after $1 \mathrm{t}$ had been exposed to air for $1 \mathrm{~d}$.

These results show that both actual and synthetic J-13 well water readily lose dissolved $\mathrm{CO}_{2}$ on exposure to air and that this $\mathrm{CO}_{2}$ loss results in a significant increase in solution $\mathrm{pH}$. In order to maintain a solution $\mathrm{pH}$ of 7.0 , it will be necessary to store the solutions and work with them in an atmosphere that contains an equilibrium partial pressure of $\mathrm{CO}_{2}$ in a controlled-atmosphere glove box or similar apparatus. These experiments suggest that an atmosphere containing slightly $<5 \% \mathrm{CO}_{2}$ in air is necessary to maintain a $\mathrm{pH}$ near 7.0 .

\subsection{BATCH CONTACT METHODOLOGY}

All of the test methodology for batch contact tests conducted under oxic, reducing, and anoxic redox conditions for the Hanford Site evaluation experiments has been reported previously (KELMERS 1985a). These methods will be modified as appropriate in order to simulate the Yucca Mountain geochemical conditions. 
Table 3.4 Concentrates for preparation of synthetic J-13 well water

\begin{tabular}{|c|c|c|c|c|}
\hline \multirow[b]{2}{*}{$\begin{array}{c}\text { Concentrate } \\
\text { No. }\end{array}$} & \multirow[b]{2}{*}{$\begin{array}{l}\text { Volume for } 1 \mathrm{~L} \\
\text { synthetic J-13 } \\
\text { (mL) }\end{array}$} & \multicolumn{3}{|c|}{ Concentrates } \\
\hline & & \multicolumn{2}{|c|}{ Constituents } & $\begin{array}{l}\text { Volume } \\
\text { prepared } \\
\text { (L) }\end{array}$ \\
\hline 1 & 100 & $\begin{array}{ll}0.04663 & \mathrm{~g} \\
81 & \mu \mathrm{L} \\
0.2561 & \mathrm{~g}\end{array}$ & $\begin{array}{l}\mathrm{MgO} \\
48 \% \mathrm{HF} \\
\mathrm{Mg}\left(\mathrm{NO}_{3}\right)_{2} \cdot 6 \mathrm{H}_{2} \mathrm{O}\end{array}$ & 2.0 \\
\hline 2 & 10 & $\begin{array}{ll}0.0100 & \mathrm{~g} \\
0.00240 & \mathrm{~g} \\
0.00183 & \mathrm{~g} \\
0.00727 & \mathrm{~g} \\
0.01412 & \mathrm{~g} \\
24 & \mu \mathrm{L}\end{array}$ & $\begin{array}{l}\mathrm{LiNO}_{3} \\
\mathrm{Sr}\left(\mathrm{NO}_{3}\right)_{2} \\
\mathrm{BaCl}{ }_{2} \cdot 2 \mathrm{H}_{2} \mathrm{O} \\
\mathrm{Fe}\left(\mathrm{NO}_{3}\right)_{3} \cdot 9 \mathrm{H}_{2} \mathrm{O} \\
\mathrm{Al}\left(\mathrm{NO}_{3}\right)_{3} \cdot 9 \mathrm{H}_{2} \mathrm{O} \\
1 \mathrm{M} \mathrm{H}_{3} \mathrm{PO}_{4}\end{array}$ & 0.20 \\
\hline 3 & 100 & $\begin{array}{ll}0.789 & \mathrm{~g} \\
0.06917 & \mathrm{~g} \\
0.2325 & \mathrm{~g}\end{array}$ & $\begin{array}{l}\mathrm{CaSO}_{4} \cdot 2 \mathrm{H}_{2} \mathrm{O} \\
\mathrm{Ca}\left(\mathrm{NO}_{3}\right)_{2} \cdot 4 \mathrm{H}_{2} \mathrm{O} \\
\mathrm{CaCl}_{2}\end{array}$ & 2.0 \\
\hline 4 & 17.06 & $\begin{array}{r}29.56 \mathrm{mg} / \mathrm{mL} \\
4.76 \mathrm{mg} / \mathrm{mL}\end{array}$ & $\begin{array}{l}\mathrm{SiO}_{2} \\
\mathrm{NaOH}\end{array}$ & $\begin{array}{l}\text { (previously } \\
\text { prepared) }\end{array}$ \\
\hline 5 & 10 & 0.3195 & $\mathrm{NaHCO}_{3}$ & 0.20 \\
\hline
\end{tabular}

Table 3.5. Carbonate, bicarbonate, and hydroxy1 ion concentrations before and after $\mathrm{pH}$ adjustment of synthetic $\mathrm{J}-13$

\begin{tabular}{lccccc} 
& & & \multicolumn{3}{c}{$\begin{array}{c}\text { Concentration } \\
\text { (meq/mL) }\end{array}$} \\
\cline { 5 - 7 } Sample & $\mathrm{pH}$ & $\mathrm{CO}_{3}{ }^{2-}$ & $\mathrm{OH}^{-}$ & $\mathrm{HCO}_{3}{ }^{-}$ & Total alkalinity \\
\hline Unadjusted & 10.7 & 0.00056 & 0.00158 & $\mathrm{a}$ & 0.00214 \\
Adjusted & 7.0 & $\mathrm{a}$ & $\mathrm{a}$ & 0.00210 & 0.00210 \\
\hline
\end{tabular}

a None present. 


\section{TECHNETIUM SORPTION/SOLUBILITY VALUES FOR HANFORD SITE BASALT/GROUNDWATER SYSTEMS}

\subsection{PUBLISHED SOLUBILITY AND SORPTION INFORMATION}

The published information describing the sorption and solubility of technetium in basalt/synthetic groundwater systems relevant to the Hanford Site candidate repository in the Columbia River basalts has been reviewed and discussed (KELMERS 1984d; BLENCOE 1985). A review and discussion of the 1iterature relevant to solubilities of technetium oxides was given in our annual report for the period October 1982-September 1983 (KELMERS 1984a). Since these reviews were written, we have received a new report (BARNEY 1983) describing the kinetics of radionuclides sorption for basalt/groundwater systems. According to this reference, under oxidizing conditions no sorption of technetium was observed on Cohassett basalt, but significant sorption was observed on Umtanum basalt. However, Barney (1983) attributes this sorption to contamination of the Umtanum basalt by particles of metallic iron. Under reducing conditions maintained by added hydrazine, signiffcant and fairly rapid sorption was observed for both Umtanum and Cohasset basalts.

\subsection{EXPERIMENTAL METHODS AND MATERIALS}

The data given in this report were obtained by use of the batch contact method, in which samples of crushed and sized basalt were contacted with synthetic groundwater. The reduction in solution concentration of the technetium was measured after a prescribed period of time. The details of this method have been described previously (KELMERS 1985a).

\subsection{RESULTS}

\subsubsection{Sorption Isotherms}

A 50-d isotherm was completed for sorption of technetium initially present as $\mathrm{TCO}_{4}$ - onto Cohassett basalt from synthetic groundwater GR-4 under anoxic conditions at $60^{\circ} \mathrm{C}$. These results, which are shown in Table 4.1, were obtained in two separate runs conducted 3 months apart. The final $\mathrm{pH}$ values of the earlier runs were $\sim 7.5$, and the final pH values of the more recent runs were $\sim 8.8$. For the more recent runs at the higher final pH, the Rs values are slightly higher. When plotted as a sorption isotherm, the data from the two runs are reasonably consistent (Fig. 4.1).

\subsubsection{Effect of Basalt Particle Size}

Experiments were conducted to measure the effect of particle size on the sorption of technetium on basalt. Two experiments are described, the first with the same samples of crushed and sized basalt used for the similar experiments with neptunium described previously (KELMERS 1985b). Because 
the results from these experiments were unexpected, in that there was little dependence of sorption on surface area, we repeated the experiments with basalt that had been freshly crushed and sized. The basalt that had been used in the previous experiment had been stored for several months in an argon-filled, controlled-atmosphere box before the initiation of that experiment. Although the oxygen is kept to a very low level in the boxes ( $<1$ ppm oxygen), even this small amount of oxygen could, in principle, react with the basalt and subsequently affect the sorption of technetium. It therefore seemed advisable to prepare a new batch of crushed and sized basalt, and use it as soon as possible after preparation. This was done, and the experiment was begun $\sim 1$ week after the basalt was prepared.

Table 4.1. Technetium sorption by Cohassett basalt from GR-4 at $60^{\circ} \mathrm{C}$ under anoxic conditions ${ }^{a}$

\begin{tabular}{|c|c|c|c|c|c|}
\hline \multirow{3}{*}{ 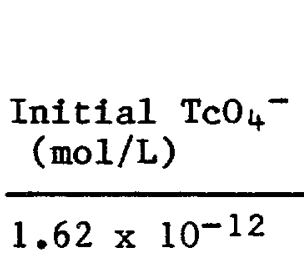 } & \multirow{3}{*}{$\begin{array}{c}\begin{array}{c}\text { Final } \\
\mathrm{pH}\end{array} \\
7.5\end{array}$} & \multirow{2}{*}{\multicolumn{2}{|c|}{$\begin{array}{c}\mathrm{Rs}^{\mathrm{b}} \\
(\mathrm{L} / \mathrm{kg})\end{array}$}} & \multicolumn{2}{|c|}{$\begin{array}{c}\text { Final concentration of } \mathrm{Tc} \\
(\mathrm{mol} / \mathrm{L})\end{array}$} \\
\hline & & & & Total & Reduced \\
\hline & & $17.7 \pm$ & 2.9 & $(5.7 \pm 0.5) \times 10^{-13}$ & $9.4 \times 10^{-14}$ \\
\hline $1.00 \times 10^{-8}$ & 7.4 & $18.3 \pm$ & 5.6 & $(3.4 \pm 0.6) \times 10^{-9}$ & $7.5 \times 10^{-10}$ \\
\hline $5.00 \times 10^{-7}$ & 8.8 & $32.8 \pm$ & 2.7 & $(1.2 \pm 0.1) \times 10^{-7}$ & $4.8 \times 10^{-8}$ \\
\hline $1.00 \times 10^{-6}$ & 7.5 & $12.1 \pm$ & 7.3 & $(4.7 \pm 1.3) \times 10^{-7}$ & $3.4 \times 10^{-8}$ \\
\hline $2.00 \times 10^{-6}$ & 8.8 & $23.6 \pm$ & 11.1 & $(4.7 \pm 1.1) \times 10^{-7}$ & $1.0 \times 10^{-7}$ \\
\hline $5.00 \times 10^{-6}$ & 8.7 & $7.4 \pm$ & 1.4 & $(2.9 \pm 0.2) \times 10^{-6}$ & $1.5 \times 10^{-7}$ \\
\hline $1.00 \times 10^{-5}$ & 8.7 & $3.2 \pm$ & 0.2 & $(7.5 \pm 0.2) \times 10^{-6}$ & $1.5 \times 10^{-7}$ \\
\hline $1.00 \times 10^{-4}$ & 7.4 & $0.3 \pm$ & 0.3 & $(9.7 \pm 0.3) \times 10^{-5}$ & - \\
\hline
\end{tabular}

aTest conditions: About $0.4 \mathrm{~g}$ of Cohassett basalt was contacted for $50 \mathrm{~d}$ at $60^{\circ} \mathrm{C}$ with $4 \mathrm{~mL}$ of synthetic groundwater GR-4 containing ${ }^{9} \mathrm{TcO}_{4}{ }^{-}$traced with $95 \mathrm{~m}_{\mathrm{TCO}_{4}}{ }^{-}$. The basalt was $-70 /+325$ mesh, ground and stored in argon. Separation of solutions from the solids was carried out by $30 \mathrm{~min}$ of centrifugation at $5000 \mathrm{rcf}$. Results are averages (with standard deviations) of three determinations. Reduced technetium concentrations were determined by solvent extraction of Tc(VII); the remaining unextracted technetium was counted and reported as reduced technetium. Because only a single determination of reduced technetium was made at each initial concentration, no standard deviations are given for reduced technetium.

$b_{R s}=$ sorption ratio. 


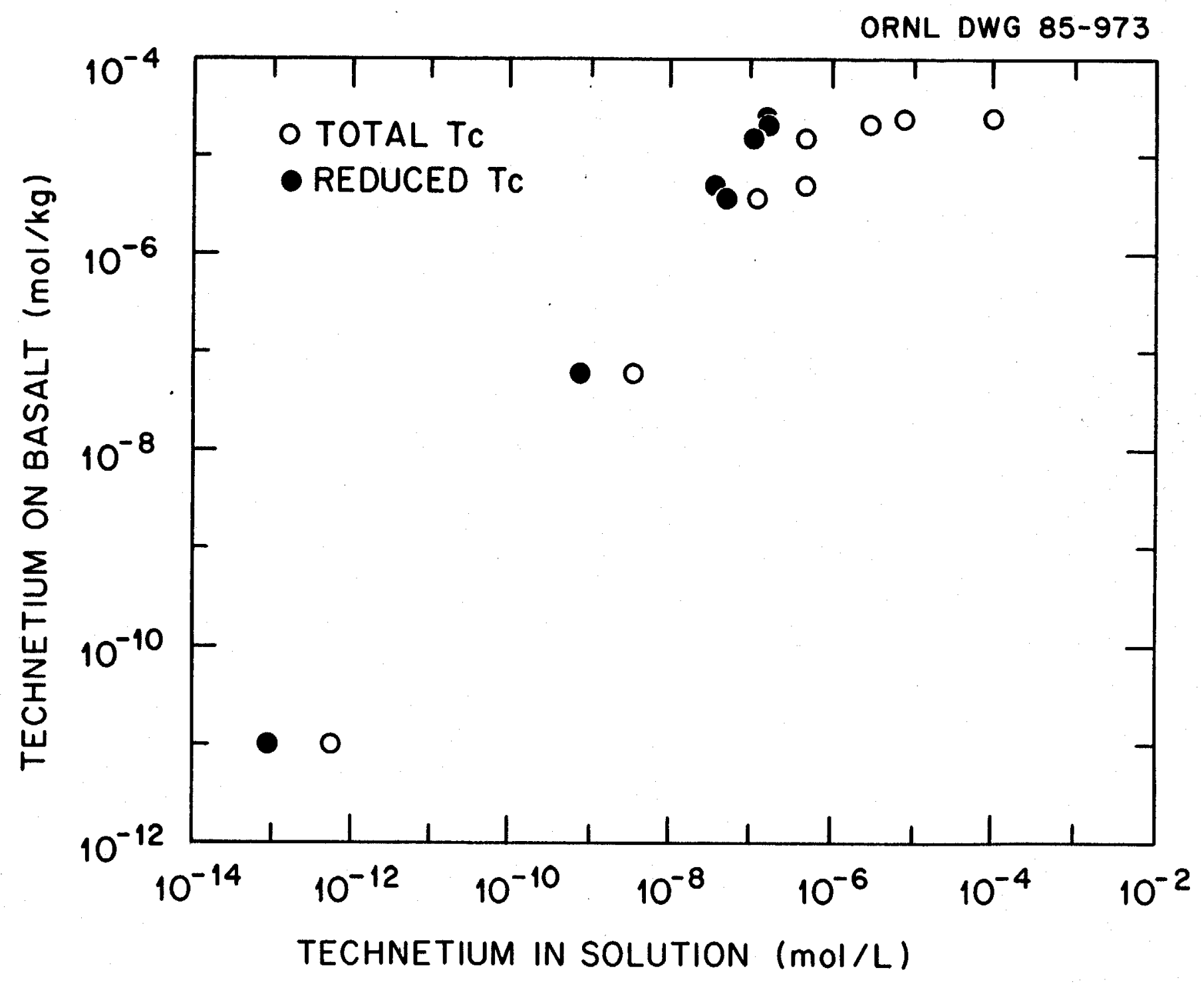

Fig. 4.1. Sorption isotherms for technetium on Cohassett basalt. Batch contact experiments were conducted under anoxic conditions with synthetic groundwater $\mathrm{GR}-4$ at $60^{\circ} \mathrm{C}$ for $50 \mathrm{~d}$. 
The results for experiments concerning the effects of particle size on sorption of technetium are given in Table 4.2. In the last two columns of the table, comparison is made between the experiments with the freshly ground and sized basalt and the experiments with the sized basalt that had been stored for several months. With the stored basalt, there is essentially no correlation between particle size and sorption ratio. In fact, the sorption ratios are surprisingly uniform and range from 21.6 to 33.2 $\mathrm{L} / \mathrm{kg}$ - For the experiments with the freshly crushed and sized basalt, the three larger-size fractions have almost the same sorption ratio, from $\sim 15$ to $22 \mathrm{~L} / \mathrm{kg}$. For the two finer fractions, the sorption ratios are about a factor of 4 to 5 larger, but the finest fraction does not have the larger sorption ratio. Thus, in this experiment, there is somewhat of a correlation between particle size and sorption ratio, but it does not in any way compare to the results obtained with neptunium in which the values range from $14.5 \pm 4.9 \mathrm{~L} / \mathrm{kg}$ for $-70 /+140$ mesh size to $275 \pm 134 \mathrm{~L} / \mathrm{kg}$ for -400 mesh size (KELMERS 1985b).

Table 4.2. Effect of particle size on sorption of $\mathrm{Tc}$ (VII)a

\begin{tabular}{lccc}
\hline & & \multicolumn{2}{c}{$\begin{array}{c}\text { Rs }^{\mathrm{b}} \\
(\mathrm{L} / \mathrm{kg})\end{array}$} \\
\cline { 3 - 4 } $\begin{array}{c}\text { Particle size } \\
(\mu \mathrm{m})\end{array}$ & Mesh size & Stored basalt & Fresh basalt \\
\hline$\langle 210 />105$ & $-70 /+140$ & $22.3 \pm 5.5$ & $15.6 \pm 3.2$ \\
$\langle 105 />74$ & $-140 /+200$ & $25.0 \pm 0.4$ & $21.7 \pm 0.4$ \\
$\langle 74 />44$ & $-200 /+325$ & $31.2 \pm 4.4$ & $22.6 \pm 0.5$ \\
$\langle 44 />37$ & $-325 /+400$ & $33.2 \pm 1.6$ & $102.6 \pm 5.5$ \\
$\langle 37$ & -400 & $21.6 \pm 0.3$ & $81.6 \pm 5.2$ \\
\hline
\end{tabular}

aTest conditions: About $0.4 \mathrm{~g}$ of Cohassett basalt was contacted with $4 \mathrm{~mL}$ of synthetic groundwater GR-4 containing ${ }^{99} \mathrm{TcO}_{4}-$ traced with ${ }^{95} \mathrm{TCO}_{4}{ }^{-}$. Initial concentration of technetium was $10^{-8} \mathrm{~mol} / \mathrm{L}$. Contact time was $50 \mathrm{~d}$ for the stored basalt and $14 \mathrm{~d}$ for the fresh basalt. Previous experiments have shown only slight differences between results for 14 and $50 \mathrm{~d}$. Conditions were anoxic at $60^{\circ} \mathrm{C}$. Separation was carried out by $30 \mathrm{~min}$ of centrifugation at $5000 \mathrm{rcf}$. The stored basalt had been stored in argon $\sim 3$ months before use; the fresh basalt was ground and sized $\sim 1$ week before use. Results are averages (with standard deviations) for three determinations.

$\mathrm{b}_{\mathrm{Rs}}=$ sorption ratio. 


\subsection{DISCUSSION}

The 50-d sorption isotherm for technetium sorption on Cohassett basalt from synthetic groundwater GR-4 is compared to the 14-d isotherm in Fig. 4.2. There appears to be no significant difference between the 14- and 50-d isotherms except perhaps in the $10^{-7}$ to $10^{-6} \mathrm{~mol} / \mathrm{L}$ concentration range. Thus, the sorption reaction appears to have attained a steady state within the 14-d duration of the experiment.

These isotherms are linear at the lower solution concentrations. At higher concentrations, the nonlinear behavior of the isotherms suggests a saturation sorption capacity of $2 \times 10^{-5}$ to $3 \times 10^{-5} \mathrm{~mol} / \mathrm{kg}$ of basalt for the Cohassett/GR-4 system. For the sorption of technetium onto McCoy Canyon basalt from synthetic groundwater GR-2, the sorption capacity is $\sim 5 \times 10^{-6}$ mol/L, 4 to 5 times smaller (KELMERS 1985b). The isotherm for reduced technetium is also linear (Fig. 4.1). Only a single extraction was used to remove the $\mathrm{TcO}_{4}{ }^{-}$from the solution, and if some of it is not removed, the residual $\mathrm{TcO}_{4}{ }^{-}$would affect the value for the reduced technetium, especially when the amount of reduced technetium is small compared to the total technetium. Thus, the values of reduced technetium concentration at the upper portion of the isotherm may be slightly high. The highest values of the concentration of reduced technetium observed in solution are on the order of $10^{-7} \mathrm{~mol} / \mathrm{L}$. At these concentrations, only a small fraction of the total technetium is reduced. The shape of the isotherm for reduced technetium is not sufficiently well defined to say whether or not a solubility-controlling solid phase is limiting the concentration. However, this concentration is not too far above solubility limits of $1 \times 10^{-8}$ to $5 \times 10^{-8} \mathrm{~mol} / \mathrm{L}$ recently obtained in ongoing work with $\mathrm{NaCl}$ solutions and synthetic groundwater GR-2 (MEYER 1985a).

The results from the particle-size experiments suggest that there may be a different mechanism for technetium sorption on basalt than for sorption of neptunium on basalt. If sorption of technetium follows a simple firstorder sorption mechanism, there would likely be a dependence on surface area or particle size as was found for neptunium (KELMERS 1985b). Therefore, it appears that the mechanism of sorption of technetium might be quite complex. The difference in the results from the experiments with stored and freshly ground basalt suggests that even slight exposure to air greatly decreases the ability of basalt to sorb technetium.

\subsection{CONCLUSIONS}

We have now completed all of the experiments currently planned for the investigation of technetium sorption on basalt. The major results for this portion of our work are summarized as follows:

1. Under oxic conditions, significant sorption of $\mathrm{TcO}_{4}{ }^{-}$is not observed with McCoy Canyon or Cohassett basalt/groundwater systems. This observation is attributed to the fact that anions are not generally absorbed by minerals, especially in alkaline solutions, and that under oxidizing conditions the basalt/groundwater system is not capable of reducing $\mathrm{TCO}_{4}-$ to species of lower valence state, which are either sparingly soluble or easily absorbed. 
ORNL DWG 85-974

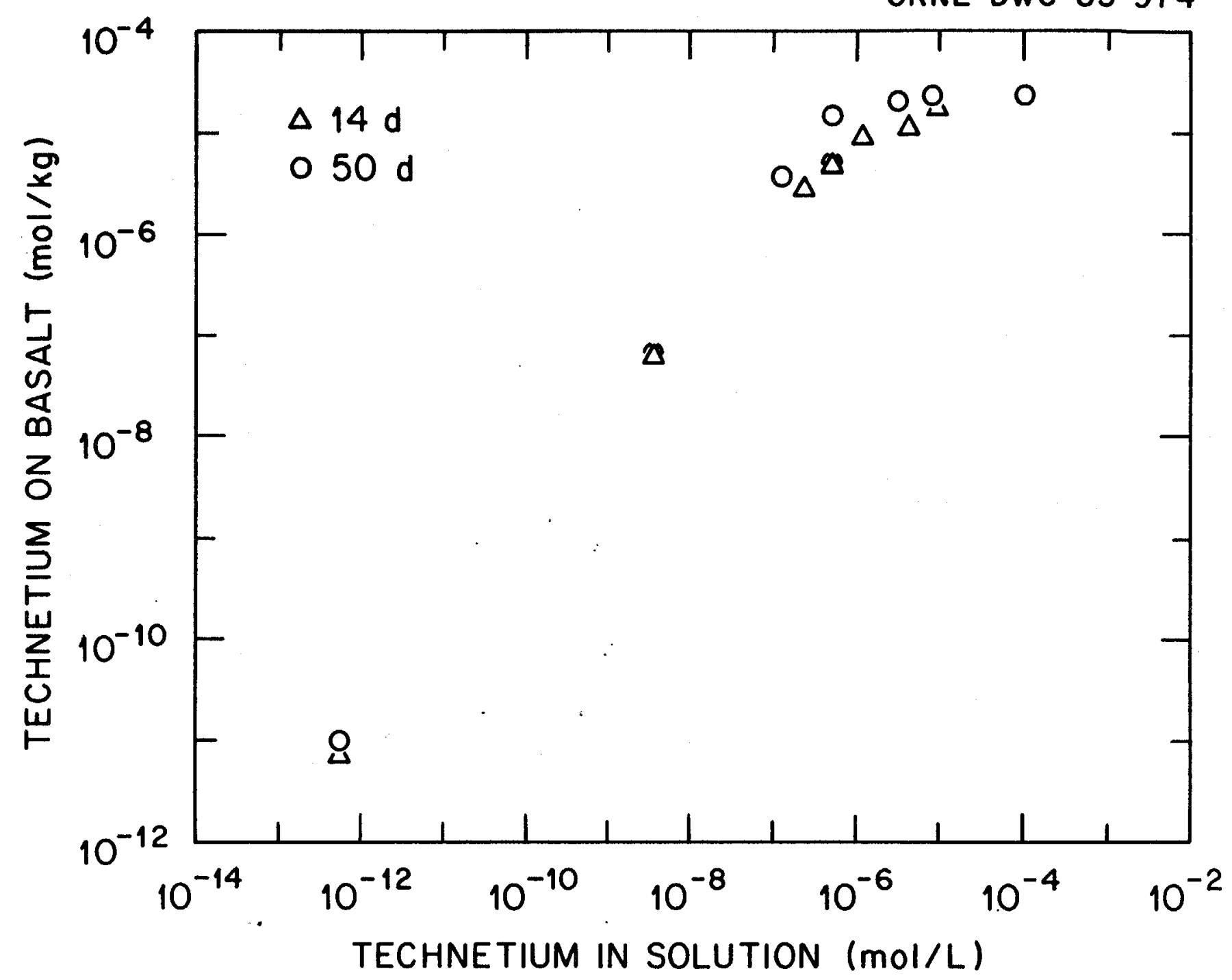

Fig. 4.2. Sorption isotherms for technetium on Cohassett basalt. Batch contact experiments were conducted under anoxic conditions with GR-4 at $60^{\circ} \mathrm{C}$ for $14 \mathrm{~d}$. 
2. Significant sorption of technetium on basalt is observed only if extremely stringent precautions are taken to remove oxygen from the groundwater. These precautions include conducting all operations of the experiment in a controlled-atmosphere box filled with argon containing < $1 \mathrm{ppm}$ oxygen and evacuating the plastic test tubes for several days prior to use to remove oxygen which may be dissolved in the plastic.

3. Significant sorption of technetium on basalt is observed only if the basalt is ground and stored in an inert atmosphere. Exposure of basalt to argon containing even $1 \mathrm{ppm}$ of oxygen was observed to gradually destroy the ability of the basalt to remove technetium.

4. Sorption isotherms are linear at low concentrations of technetium. This characteristic indicates that the amount of sorbed technetium is directly proportional to the solution concentration of technetium over the important trace concentration region. This result should simplify mathematical modeling of the sorption of technetium on basalt.

5. Sorption ratios are somewhat higher for Cohassett basalt in GR-4 compared with McCoy Canyon basalt in GR-2. Sorption isotherms indicate a saturation capacity of 2 to $3 \times 10^{-5} \mathrm{~mol} / \mathrm{kg}$ for technetium sorption onto Cohassett basalt from GR-4 and a capacity of about $5 \times 10^{-6} \mathrm{~mol} / \mathrm{kg}$ for sorption onto McCoy Canyon basalt from GR-2. It is possible that the greater sorption observed with the Cohassett system resulted from characteristic differences in the quantity of mesostasis and the $\mathrm{Fe}$ (II) content of the Cohassett basalt mesostasis (KELMERS 1985a). However, it is also possible that differences in the composition of the two different groundwaters could account for the greater sorption observed with the Cohassett system. In experiments designed to investigate effects of solution composition, we found higher sorption ratios when bicarbonate and/or silica were removed from the solution (KELMERS 1985c).

6. Unlike sorption of neptunium on basalt, sorption of technetium on basalt is not very sensitive to particle size, and this sensitivity disappears completely as the basalt is stored in the controlled-atmosphere boxes that contain argon with $<1 \mathrm{ppm}$ oxygen.

7. The use of hydrazine to simulate reducing conditions relevant to a repository in the laboratory is a questionable procedure. The chemical path of the reduction of nuclides such as technetium and neptunium is quite complex and does not necessarily correspond to the chemical path expected in reducing repository environments. Also, a procedure using a reducing agent to produce lower valence states of nuclides implicitly assumes that the repository environment will cause reduction. In fact, one of the principal uncertainties is whether or not the repository environment will be capable of causing reducing conditions. The reasons for these conclusions have been previously discussed in considerable detail (KELMERS 1984b). 
In our earlier work with the technetium and neptunium basalt systems (KELMERS 1984a), we obtained sorption isotherms on basalt in the presence of hydrazine. We reported apparent concentration limits for technetium that were on the order of $10^{-6} \mathrm{~mol} / \mathrm{L}$, when the experiments were conducted in glass, and $10^{-5} \mathrm{~mol} / \mathrm{L}$, when the experiments were done in plastic test tubes. The plastic test tubes probably contained oxygen that reoxidized $\mathrm{Tc}(\mathrm{IV})$ to $\mathrm{TCO}_{4}{ }^{-}$. In these earlier experiments, we did not distinguish between $\mathrm{Tc}$ (VII) and Tc(IV) (or other possible lower valence states). In addition, some of the reduced technetium may have been present as colloids. In some later experiments, considerable technetium was filtered out of the solution by ultrafiltration. The nature of the colloids is unknown, but there was some evidence that the colloids may be associated with the silica in the solutions. We therefore now feel that the values for these apparent concentration limits are too high.

8. The sorption of technetium on basalt is being investigated in more detail in the NRC Research Program, Valence Effects on Sorption (B0462), and some aspects of the mechanism have been clarified. Results to date (MEYER 1983, MEYER 1984, MEYER 1985b) are brlefly summarized below.

a. Valence analysis shows that much of the technetium sorbed on the basalt is reduced to a lower valence state, possibly Tc(IV). It is not yet clear whether the technetium is reduced on the surface or in the solution near the basalt surface. The technetium sorbed on basalt is difficult to remove from the surface of the basalt. Thus, substantial sorption/desorption disequilibrium exists with this system.

b. Sorption of technetium is quite sensitive to the composition of the solution; for example, sorption from pure NaCl solutions is significantly greater than that from synthetic groundwaters.

c. The kinetics of technetium sorption appear to be quite slow. In recirculating colum tests, technetium was slowly removed from solution over periods of several months.

d. If basalt/groundwater systems are capable of reducing technetium, then solubilities of reduced oxides might control the maximum solution concentration of technetium. Therefore, solubilities of Tc(IV) oxides are being determined over the $\mathrm{pH}$ region 1 to 10 in various solutions (MEYER 1985a, MEYER 1985b). The results obtained so far indicate that in $\mathrm{NaCl}$ solutions solubilities of $\mathrm{Tc}$ (IV) oxides are $\sim 1 \times 10^{-8}$ to $5 \times 10^{-8} \mathrm{~mol} / \mathrm{L}$ in the $\mathrm{pH}$ region 4 to 9 . However, these results are from ongoing measurements, and so far measurements have not been made in $\mathrm{GR}-4$ at $60^{\circ} \mathrm{C}$. These measurements take into account the presence of aqueous species of $\mathrm{Tc}$ (IV), and solvent extraction procedures are used to distinguish between species of $\mathrm{Tc}$ (IV) and Tc(VII). 


\subsection{EVALUATION OF PUBLISHED INFORMATION}

A variety of technetium solubility values have been published by the BWIP (Table 4.3). Initially, calculated solubility values $\geqslant 10^{-14} \mathrm{~mol} / \mathrm{L}$ were reported for the reducing conditions that the BWIP expects to exist in the repository. These minimum values were calculated solely from the Tc(VII)/ Tc(IV) redox equilibrium with the assumption that the only aqueous species of technetium is $\mathrm{TcO}_{4}{ }^{-}$. No data on solubility of $\mathrm{Tc}$ (IV) oxides in synthetic groundwaters were available, and therefore, any significant presence of $\mathrm{Tc}$ (IV) aqueous species was neglected. The more recent references have tended toward higher solubility values based, in part, on experimental observations. The work supported by NRC Research (B0462) to obtain a more accurate measurement of the solubility of Tc(IV) oxides suggests that the solubility may be in the range of $1 \times 10^{-8}$ to $5 \times 10^{-8} \mathrm{~mol} / \mathrm{L}$. Thus, the expected values given in the later BWIP publications may be close to the actual solubility for Tc(IV) solids in groundwaters, but may not be especially conservative.

Table 4.3 Technetium solubility values published by the BWIP

\begin{tabular}{lcc}
\hline \multicolumn{1}{c}{ Reference } & $\begin{array}{c}\text { Technetium } \\
(\mathrm{mol} / \mathrm{L})\end{array}$ & Comment \\
\hline EARLY 1982, EARLY 1984 & $>10^{-14}$ & Eh $=-0.3 \mathrm{~V}$ \\
SALTER 1983 & $1 \times 10^{-9}$ & $\begin{array}{c}\text { "expected" } \\
\text { "conservative" }\end{array}$ \\
DOE 1984b & $1 \times 10^{-5}$ & \\
\hline
\end{tabular}

The technetium Rs values reported by the BWIP are summarized in Table 4.4 . With the exception of tests involving Umtanum basalt, essentially no sorption was observed under oxidizing conditions, and Rs values of $0 \mathrm{~L} / \mathrm{kg}$ were reported. Under reducing conditions (hydrazine added) or with Umtanum basalt even under oxidizing conditions, sorption ratios of 20 to $30 \mathrm{~L} / \mathrm{kg}$ were reported. Contamination of the standard Umtanum basalt sample by iron particles from the grinding equipment used to pulverize the sample was suggested as the cause of the anomalous sorption of technetium under oxidizing conditions (BARNEY 1983, MEYER 1984). While it may be coincidental, we also obtained $R$ s values in the range of 20 to $30 \mathrm{~L} / \mathrm{kg}$ under anoxic conditions with Cohassett basalt.

If technetium is present in the groundwaters in the oxidized state, as $\mathrm{Tc}$ (VII), then it will most likely be present as the anion $\mathrm{TCO}_{4}{ }^{-}$. As with other anions, $\mathrm{TcO}_{4}{ }^{-}$is not 1 ikely to be sorbed by the rocks and minerals present in basalt formations under the normal conditions of the groundwaters. Thus, if $\mathrm{Tc}$ (VII) is to be significantly sorbed, it must be reduced and either sorbed, precipitated, or otherwise incorporated into a solid. 
We have shown that exceptional conditions must be met before basalt can be shown to sorb $\mathrm{Tc}$ (VII) in laboratory experiments. If even small amounts of oxygen are present in the groundwaters, there is not likely to be significant sorption. Thus, if the BWIP is to predict significant sorption of $\mathrm{Tc}$ (VII) by basalt in an actual repository situation, then they must demonstrate (1) that the oxygen level is as low as the level that we have maintained in our anoxic boxes, and (2) perhaps most important, that the surface condition of the basalt which contacts the groundwater is comparable (or has comparable sorption characteristics) to that of freshly ground basalt. Furthermore, if these two conditions can be demonstrated, then the limited saturation capacity of basalt must be taken into account in calculations of retardation.

Table 4.4 Technetium sorption (Rs) values published by the BWIP

\begin{tabular}{|c|c|c|}
\hline Reference & $\begin{array}{c}\text { Rs } \\
(\mathrm{L} / \mathrm{kg})\end{array}$ & Comment \\
\hline SALTER 1981 & $\begin{array}{l}0 \\
26.8 \pm 21.9 \\
25 \quad \pm 5.2 \\
29 \quad \pm 2.5\end{array}$ & $\begin{array}{l}\text { Flow E basalt, } 23^{\circ} \mathrm{C} \text {, oxidizing } \\
\text { Umtanum basalt, } 23^{\circ} \mathrm{C} \text {, oxidizing } \\
\text { Umtanum basalt, } 60^{\circ} \mathrm{C} \text {, oxidizing } \\
\text { Umtanum basalt, } 23^{\circ} \mathrm{C} \text {, reducing }\end{array}$ \\
\hline SCR 1982 & $\begin{array}{r}0 \\
29\end{array}$ & $\begin{array}{l}\text { oxidizing } \\
\text { reducing }\end{array}$ \\
\hline SALTER 1983 & $\begin{array}{r}15 \\
0\end{array}$ & $\begin{array}{l}\text { "expected" } \\
\text { "conservative" }\end{array}$ \\
\hline DOE $1984 b$ & 0 to 15 & \\
\hline
\end{tabular}

The geochemical conditions pertinent to the retardation of technetium migration at the Hanford Site will be different in the engineered facility and in the far fleld. Basalt that is used for backfill or overpack will have been mined and exposed to air during surface storage. Even if basalt is freshly crushed immediately before use, it will st111 be exposed to air for significant lengths of time in the repository before anoxic conditions are established. Thus, it is possible that this basalt may have little, if any, capacity to reduce technetium. Temperatures used in the engineered facility may be considerably higher than the $60^{\circ} \mathrm{C}$ used in our experiments. The removal of dissolved oxygen by crushed Umtanum basalt has been investigated by Lane (1984). At $100^{\circ} \mathrm{C}$, the lowest temperature investigated in these experiments, it was observed that the dissolved oxygen content of synthetic groundwater initially containing $\sim 8.8 \mathrm{mg} / \mathrm{L}$ of dissolved oxygen (air saturation) decreased to $\sim 2 \mathrm{mg} / \mathrm{L}$ when the experiment was terminated after $3000 \mathrm{~h}$. At $150^{\circ} \mathrm{C}$, a decrease to $0.4 \mathrm{mg} / \mathrm{L}$ was observed after $200 \mathrm{~h}$. Thus, the removal process appears to be very sensitive to temperature. Lane (1984) suggests that the ferrous iron content of the basalt is involved in the removal process. However, these experiments did not distinguish between reduction of oxygen and diffusion of oxygen into the basalt. Although 
we agree that the reduction of dissolved oxygen is a likely mechanism of removal, we also feel that sorption of dissolved oxygen is a possibility. In both the 100 and $150^{\circ} \mathrm{C}$ experiments, reported by Lane (1984), the remaining dissolved oxygen content could very probably prevent reduction of technetium. It seems to be implicitly assumed by Lane (1984) that eventually all of the dissolved oxygen would be removed by the basalt.

In the far field, the release pathway for migrating groundwater containing dissolved technetium would be through fractures and fissures as well as along the porous basalt flow top. These structures are known to be lined with secondary minerals such as clays, zeolites, and calcite. These secondary minerals, which do not sorb technetium themselves (SALTER 1983), may effectively inhibit contact between the groundwater and the intact interior of the basalt. We are concerned that the experimental methodology used by the BWIP and in our work, which involved crushing the basalt to yield a powdered material, may be poorly related to in situ conditions because it offered no opportunity to explore the possible effects of coating of the basalt surfaces by secondary minerals. Our results suggest that the various basalts have an inherent capability to sorb technetium [presumably by reduction to $\mathrm{Tc}$ (IV) species] when the oxygen content of the rock/groundwater system is sufficiently low. It remains to be demonstrated that such reducing conditions actually exist in the candidate repository horizon and likely flow paths to the accessible environment.

We conclude that both the experimental methodology and results reported by the BWIP to date for technetium sorption or solubility behavior do not conclusively indicate that significant retardation of technetium may be provided by phases present in the basalts at the Hanford Site. Additional consideration of technetium geochemistry may be necessary if the Hanford Site performance assessment strategy will require significant retention of technetium by the site. 


\section{URANIUM SORPTION/SOLUBILITY VALUES FOR HANFORD SITE BASALT/GROUNDWATER SYSTEMS}

\subsection{PUBLISHED SOLUBILITY AND SORPTION INFORMATION}

A summary of the published information describing uranium solubility limits or sorption distribution coefficients relevant to the candidate repository site in the Columbia River basalts was given in a previous report (KELMERS 1984d). The basalt site sorption and solubility information has also been separately reviewed and assessed (BLENCOE 1985; KELMERS 1984a).

\subsection{RESULTS}

During the current report period, we completed isotherms for uranium sorption onto Cohassett basalt from synthetic groundwater GR-4. Results for these determinations are given in Table 5.1, and the isotherms are plotted in Fig. 5.1. We previously described sorption isotherms for uranium onto McCoy Canyon basalt from synthetic groundwater GR-2 (KELMERS 1985a).

Table 5.1. Uranium sorption onto Cohassett basalta

\begin{tabular}{|c|c|c|c|}
\hline \multirow{2}{*}{$\begin{array}{l}\text { Initial } \\
\text { concentration } \\
(\operatorname{mol} / \mathrm{L})\end{array}$} & \multirow[b]{2}{*}{$\mathrm{pH}$} & \multicolumn{2}{|c|}{$\begin{array}{c}\mathbf{R s}^{\mathrm{b}} \\
(\mathrm{L} / \mathbf{k g})\end{array}$} \\
\hline & & $14 d$ & $50 \mathrm{~d}$ \\
\hline $9.8 \times 10^{-8}$ & 8.6 to 8.8 & $31.1 \pm .4 .5$ & $313 \pm 71$ \\
\hline $9.9 \times 10^{-7}$ & 8.5 to 8.8 & $30.7 \pm 6.0$ & $236 \pm 48$ \\
\hline $1.05 \times 10^{-5}$ & 8.5 to 8.8 & $19.4 \pm 1.8$ & $115 \pm 28$ \\
\hline $1.03 \times 10^{-4}$ & 8.5 to 8.7 & $355 \pm 54$ & $1288 \pm 52$ \\
\hline \multicolumn{4}{|c|}{$\begin{array}{l}\text { aTest conditions: About } 0.4 \mathrm{~g} \text { Cohassett basalt } \\
\text { was contacted with } 4 \mathrm{~mL} \text { of synthetic groundwater GR-4. } \\
\text { Basalt was }-70 /+325 \text { mesh size, crushed and stored } \\
\text { under argon. Separation was carried out by } 30 \text { min of } \\
\text { centrifugation at } 5000 \mathrm{rcf} \text {. Each Rs value is the } \\
\text { average (with } \pm 1 \text { standard deviations) of three deter- } \\
\text { minations. The tests were under anoxic conditions at } \\
60^{\circ} \mathrm{C} \text {. }\end{array}$} \\
\hline
\end{tabular}




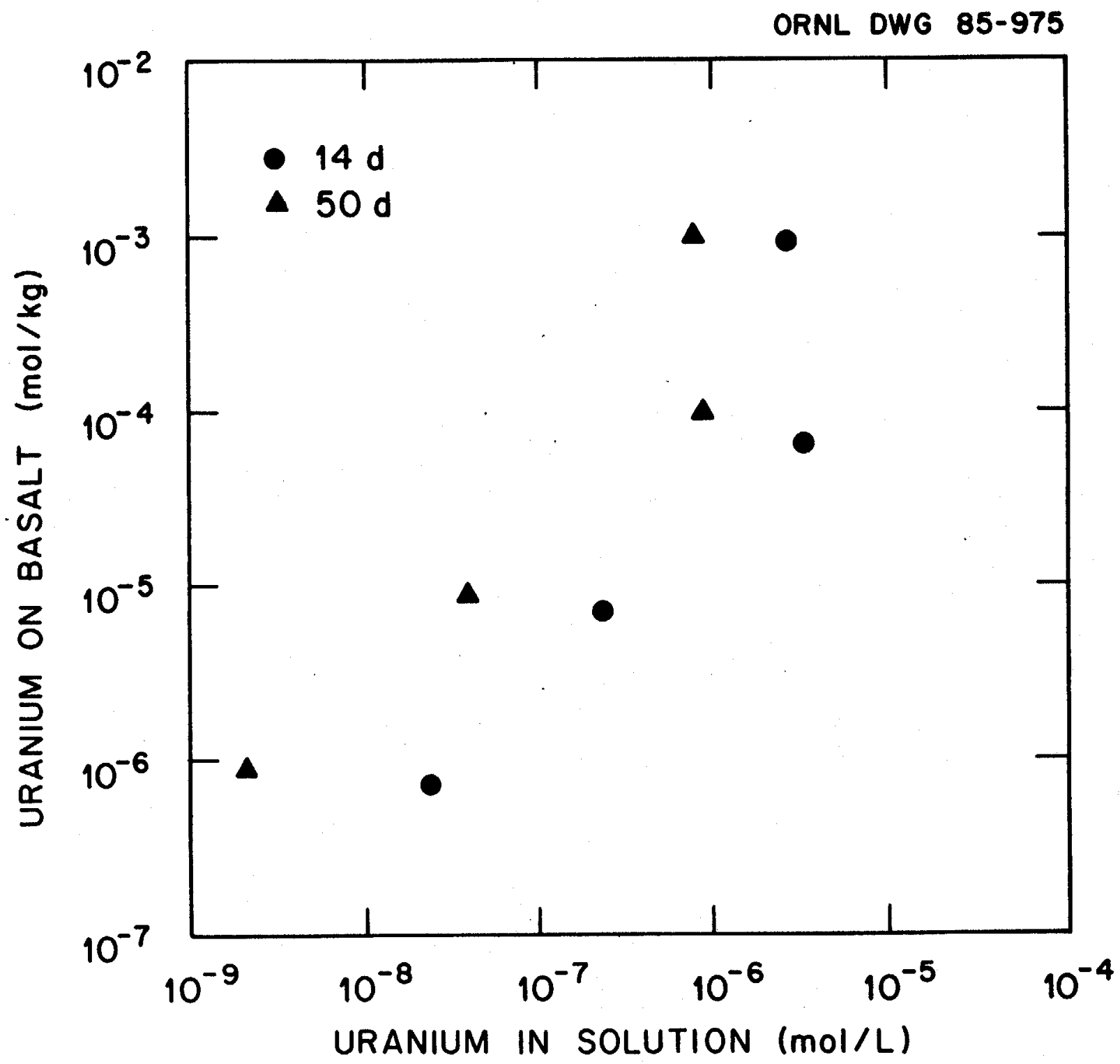

Fig. 5.1. Sorption isotherms for uranium on Cohassett basalt. Batch contact experiments were conducted under anoxic conditions with synthetic groundwater GR-4 at $60^{\circ} \mathrm{C}$. 
We have previous1y reported (KELMERS 1985b) the formation of a lightyellow precipitate in blank tests (no basalt present) with GR-2 for initial concentrations of $10^{-4} \mathrm{~mol} / \mathrm{L}$ uranium at $60^{\circ} \mathrm{C}$ under oxic and anoxic conditions. We prepared enough of this precipitate for XRD analysis by the following procedure:

About $0.3 \mathrm{~g}$ of $\mathrm{UO}_{3}$ was dissolved in an $\mathrm{HCl}$ solution and evaporated to dryness. The resulting solid, uranyl chloride, was dissolved in water and again evaporated to dryness. This procedure was repeated, and a stock solution of $238 \mathrm{U}$ was prepared from the resulting solid. Enough of this stock solution was added to freshly prepared synthetic groundwater GR-2 to make $500 \mathrm{~mL}$ of a solution that contained $10^{-4} \mathrm{~mol} / \mathrm{L}$ of uranium. This mixture was then traced with $233 \mathrm{U}$, transferred to two $250-\mathrm{mL}$ bottles, and placed into a controlled-atmosphere box containing argon. The samples were then agitated for $24 \mathrm{~d}$ at $60^{\circ} \mathrm{C}$. After they were removed, a light-yellow prectpitate was observed in the bottles, and the test solution was observed to contain $7.5 \times 10^{-6}$ mol/L of uranium. The solid was separated by centrifugation in the controlled-atmosphere box and submitted for XRD analysis.

The results indicate that the precipitate was sodium boltwoodite, $\mathrm{Na}\left(\mathrm{UO}_{2}\right)\left(\mathrm{SiO}_{3}\right)(\mathrm{OH}) \cdot 5 / 2 \mathrm{H}_{2} \mathrm{O}$. The same procedure was repeated using $\mathrm{GR}-4$ instead of GR-2. Again the light-yellow precipitate was formed, and $\mathrm{XRD}$ analysis showed that it was sodium boltwoodite.

\subsection{DISCUSSION}

The data in Table 5.1 and Fig. 5.1 show a large increase in Rs at the highest concentration of uranium; the sorption isotherms are typical of those found for sorption at low concentrations followed by precipitation at the higher concentrations. There is a significant increase in Rs between the 14-d and 50-d contact time periods. Sorption ratios are almost a factor of 10 larger for the 50-d tests. There are significant reductions in uranium concentrations from the control solutions at the highest uranium concentration and some loss from the second highest concentration. This behavior is a clear indication of preclpitation of urantum from the solution.

For anoxic conditions, there are significant differences in sorption behavior for the two basalt/groundwater systems that we have studied. For the McCoy Canyon/GR-2 system, the values of Rs were in the range of $2-4 \mathrm{~L} / \mathrm{kg}$, with little difference noted between the 14-d and 50-d runs. For the Cohassett/GR-4 system, the values of Rs were much larger, and there was a significant difference between the $14-d$ and the $50-d$ systems.

Since the McCoy Canyon runs were completed last summer, we have been careful to use very stringent oxygen-removal techniques for all anoxic experiments. In particular, we have been evacuating the test tubes for the $3 \mathrm{~d}$ prior to use. Whether this will make a difference for uranium sorption, as it did for technetium, is not yet established. However, we have underway the last 
run for the McCoy Canyon basalt and GR-2 $50-\mathrm{d}, 60^{\circ} \mathrm{C}$ isotherm. The completion of this run should tell us whether these more careful oxygen-removal techniques will affect sorption of uranium under anoxic conditions.

We have reported previously (KELMERS 1985a) that we are observing concentration limits for uranium that are lower than the value, $10^{-4} \mathrm{~mol} / \mathrm{L}$, that was reported in the SCR (1982) for oxic conditions [under which U(VI) compounds are stable]. For the anoxic experiments reported here, the concentrations were $2.66 \times 10^{-6} \mathrm{~mol} / \mathrm{L}$ for the $14-\mathrm{d}$ experiment and $7.73 \times 10^{-7}$ $\mathrm{mol} / \mathrm{L}$ for the $50-\mathrm{d}$ experiment at $10^{-4} \mathrm{~mol} / \mathrm{L}$ of initial uranium. We have observed formation of a light-yellow precipitate of sodium boltwoodite under both oxic and anoxic conditions. The oxidation state of uranium in sodium boltwoodite is (VI). Uranium(VI) is normally expected under oxic conditions and was present in these experiments under anoxic conditions. It would therefore seem reasonable to extrapolate these solubility limits to oxic conditions for the Cohassett/ basalt GR-4 system, although we have not specifically determined isotherms under oxic conditions for this system. A solubility limit of $2 \times 10^{-10} \mathrm{~mol} / \mathrm{L}$ was calculated for $\mathrm{UO}_{2}$ in a reference groundwater under reducing conditions (EARLY 1982; EARLY 1984). This value is considerably lower than the solubility limits that we observe in the anoxic experiments reported here. Should boltwoodite be the controlling solid phase in a repository, the concentration of uranium could be higher than that calculated for $\mathrm{UO}_{2}$ by Early $(1982,1984)$. However, the actual equilibrium solubility of boltwoodite is not known, and it is possible that with longer reaction time, the uranium concentration in our experiments would become lower than our last observed value.

Because thermodynamic data are not available for boltwoodite, geochemical model calculations cannot simulate the precipitation of this phase. Therefore, calculations for oxic conditions will probably overestimate total uranium concentration because schoepite, an apparently more soluble phase, is usually assumed to be the controlling solid phase. Under anoxic conditions, where $\mathrm{UO}_{2}$ or other U(IV) phases are thought to control uranium concentration, model calculations may underestimate total uranium concentration. These results illustrate the importance of identifying the solid phases present in experimental measurements and some possible limitations associated with the use of incomplete thermodynamic data in geochemical modeling. 


\section{GEOCHEMICAL MODELING - RADIONUCLIDE SOLUBILITY/SPECIATION INFORMATION RELEVANT TO YUCCA MOUNTAIN}

Solubility/speciation calculations using geochemical models (e.g., EQ3/6) are being used by NNWSI to estimate radionuclide source terms and to evaluate the nature of various geochemical characteristics of the Yucca Mountain site (KERRISK 1983; KERRISK 1984a; OGARD 1984). Calculations such as these are sensitive to the assumptions, boundary conditions, and thermodynamic data upon which they are based. Therefore, efforts were initiated during this quarter to attempt to verify some of the solubility/speciation calculations performed to date that are relevant to the Yucca Mountain site.

\subsection{PUBLISHED INFORMATION}

Ogard and Kerrisk (OGARD 1984) discuss aspects of the groundwater chemistry along various potential flow paths from the Yucca Mountain site to the accessible environment. They present results of solubility/speciation calculations for $\mathrm{U}, \mathrm{Pu}, \mathrm{Am}, \mathrm{Sr}, \mathrm{Tc}$, and $\mathrm{Ra}$ in three different groundwater formulations representative of the subsurface hydrologic system. They also present results of calculations quantifying the $\mathrm{pH}$ and $\mathrm{Eh}$ buffering capacity of the groundwaters. For the solubility/speciation calculations, Ogard and Kerrisk (OGARD 1984) used EQ3/6 to simulate the equilibration of each water with a specific solid phase assumed to control the solubility of a given radionuclide. In this manner, they obtained an estimate of the total concentration and aqueous speciation for the radionuclide in the groundwater of interest. The solubility/speciation calculations were performed for three representative groundwaters (see Table 6.1). The temperature assumed for the calculations is not given, but it is likely that $25^{\circ} \mathrm{C}$ was used, as data for elevated temperature are generally not available for the elements addressed.

\subsection{EVAULATION METHODS}

The solubility/speciation calculations of Ogard and Kerrisk (OGARD 1984) were duplicated using MINTEQ (FELMY 1984) to provide a verification of the results using an independent computer code and data base (to the extent possible). Only calculations for $\mathrm{U}, \mathrm{Pu}, \mathrm{Am}$, and $\mathrm{Sr}$ were evaluated because no thermodynamic data for technetium and radium were available in a format compatible with MINTEQ at the time our calculations were completed. This approach of comparing independent calculations of the solubility/speciation behavior of several radionuclides can yleld useful insights into potential inconsistencies and problems associated with assumptions and thermodynamic data bases used for solubility/speciation calculations.

For each groundwater modeled, $\mathrm{pH}$ and Eh were assigned fixed activities according to the solution compositions listed in Table 6.1. Groundwater J-13 does not have a reported Eh but exhibits a dissolved oxygen content of $5.7 \mathrm{mg} / \mathrm{L}$. Kerrisk, in an earlier report (KERRISK 1984a), stated that assuming an Eh of $+700 \mathrm{mV}$ for J-13 groundwater was appropriate for geochemical calculations, but he provided little justification for this choice of Eh. The value of $+700 \mathrm{mV}$ is close to the theoretical value of $+800 \mathrm{mV}$ for 
a solution containing $5.7 \mathrm{mg} / \mathrm{L}$ of dissolved oxygen at a $\mathrm{pH}$ of 6.9 . Therefore, an $\mathrm{Eh}$ of $+800 \mathrm{mV}$ was used for all calculations involving J-13 groundwater, except for plutonium. To obtain close agreement with the results of Ogard and Kerrisk (OGARD 1984) for plutonium solubility/speciation, an assumed $\mathrm{Eh}$ of $+700 \mathrm{mV}$ was required. This sensitivity of plutonium solubility/speciation to small differences in Eh is discussed in more detail in Sect. 6.3.4. A temperature of $25^{\circ} \mathrm{C}$ was assumed for all calculations.

Table 6.1. Composition of groundwaters used in the comparative solubility/speciation calculations ${ }^{a}$

\begin{tabular}{|c|c|c|c|}
\hline \multirow{2}{*}{ Constituent } & \multicolumn{3}{|c|}{$\begin{array}{l}\text { Concentration } \\
(\mathrm{mg} / \mathrm{L})\end{array}$} \\
\hline & $\begin{array}{r}\text { Sample } \\
\text { USW H-3 }\end{array}$ & $\begin{array}{l}\text { Sample } \\
\mathrm{J}-13\end{array}$ & $\begin{array}{c}\text { Sample } \\
\mathrm{UE}-25 \mathrm{p} \text { 非 }\end{array}$ \\
\hline $\mathrm{Ca}$ & 0.8 & 11.5 & 87.8 \\
\hline $\mathrm{Na}$ & 124 & 45. & 171 \\
\hline $\mathrm{Mg}$ & 0.01 & 1.76 & 31.9 \\
\hline $\mathrm{k}$ & 1.5 & 5.3 & 13.4 \\
\hline Li & 0.22 & 0.06 & 0.32 \\
\hline $\mathrm{Fe}$ & 0.13 & 0.04 & $<0.1$ \\
\hline Mn & 0.01 & 0.001 & $<0.1$ \\
\hline A1 & 0.51 & 0.03 & 0.1 \\
\hline Si & $16.9^{\circ}$ & 30.0 & 30 \\
\hline $\mathrm{Cl}$ & 8.3 & 6.4 & 37 \\
\hline $\mathrm{F}$ & 5.4 & 2.1 & 3.5 \\
\hline $\mathrm{SO}_{4}$ & 31.2 & 18.1 & 129. \\
\hline $\mathrm{NO}_{2}$ & $<0.1$ & $\mathrm{ND}^{\mathrm{b}}$ & ND \\
\hline $\mathrm{NO}_{3}$ & 0.2 & 10.1 & $<0.1$ \\
\hline $\mathrm{O}_{2}$ & $<0.1$ & 5.7 & $\mathrm{NR}^{\mathrm{C}}$ \\
\hline $\begin{array}{l}\text { a1kalinity, } \\
\text { meq/L }\end{array}$ & 4.72 & 2.34 & 11.44 \\
\hline $\mathrm{Eh}, \mathrm{mV}$ & -143 & $\mathrm{ND}$ & 360 \\
\hline $\mathrm{pH}$, ph units & 9.4 & 6.9 & 6.7 \\
\hline
\end{tabular}

aTaken from OGARD 1984. A. E. Ogard and J. F. Kerrisk, Groundwater Chemistry Along Flow Paths Between a Proposed Repository Site and the Accessible Environment, LA-10188-MS, Los Alamos Nationa1 Laboratory, Los Alamos, New Mexico, 1984.

$\mathrm{b}_{\mathrm{ND}}=$ not detected.

$\mathrm{c}_{\mathrm{NR}}=$ not reported

The same solids as those specified by Ogard and Kerrisk (OGARD 1984) were assigned to control solubilities in our calculations. The distribution of aqueous species for each radionuclide in our calculations is based on the thermodynamic data that were available for the MINTEQ code at the time of 
the calculations. No attempt was made to critically evaluate these thermodynamic data. Although such a critical evaluation is badly needed, this activity is beyond the scope of our activities. The distribution of aqueous species for uranium and strontium is based on the compilation of data that is included with MINTEQ (FELMY 1984). This uranium data base has been evaluated in detail by Krupka et al. (KRUPKA 1983). Thermodynamic data for plutonium and americium were taken from the compilation of Early et al. (EARLY 1982). These data have been used previously in an evaluation of solubility/speciation calculations relevant to the Hanford site (KELMERS 1984c). Some adjustments to the thermodynamic data base for plutonium were required to obtain close agreement with the results of Ogard and Kerrisk (OGARD 1984). This manipulation of data is discussed in more detail in Sect. 6.3.4.

\subsection{RESULTS}

\subsubsection{Uranium}

Table 6.2 summarizes the results of the comparison calculations performed for urantum. For each of the groundwaters, the spectfied solid phase is calculated to be the most stable solid. The calculated solubilities are in fair agreement with the results of Ogard and Kerrisk (OGARD 1984). The aqueous speciation for uranium is in close agreement for groundwaters USW H-3 and UE-25p非. Our calculations result in the same predominant species obtained by Ogard and Kerrisk (OGARD 1984), although the actual percentages are somewhat different. This variation can probably be attributed to small differences in the $\log (K)$ values for the aqueous complexes of uranium in the thermodynamic data we used versus that used by Ogard and Kerrisk (OGARD 1984). For groundwater J-13, the aqueous speciation is not in close agreement. Ogard and Kerrisk (OGARD 1984) calculate $\left(\mathrm{UO}_{2}\right)_{2} \mathrm{CO}_{3}(\mathrm{OH})_{3}^{-}$to be the dominant species, whereas we calculate the dominant complex to be $\mathrm{UO}_{2}\left(\mathrm{CO}_{3}\right)_{2}{ }^{2-}$. This discrepancy results because MINTEQ (FELMY 1984) does not contain thermodynamic data for the species $\left(\mathrm{UO}_{2}\right)_{2} \mathrm{CO}_{3}(\mathrm{OH})_{3}{ }^{-}$. The inclusion of data for this apparently strong complex in the data base for $E Q 3 / 6$ probably also explains the somewhat higher solubilities for uranium in $\mathrm{J}-13$ and UE-25p $\equiv 1$ calculated by Ogard and Kerrisk (OGARD 1984) as compared to ours.

\subsubsection{Strontium}

As seen in Table 6.3, our calculated results for the solubility/speciation of strontium are in excellent agreement with those of Ogard and Kerrisk (OGARD 1984). The calculated solubilities are all within a factor of 2. For each of the groundwaters, strontianite is calculated to be the most stable solid phase. The aqueous speciation is also in close agreement. The lack of $\mathrm{SrSO}_{4}{ }^{\circ}$ as the subordinate species in our calculations can be attributed to the fact that MINTEQ does not contain any thermodynamic data for this species. The presence of this species in the calculations of Ogard and Kerrisk (OGARD 1984) probably accounts for the slightly higher calculated solubilities for strontianite in their calculations as compared to ours. 
Table 6.2. Comparison of calculated uranium solubility/speciationa

\begin{tabular}{|c|c|c|c|}
\hline & $\begin{array}{l}\text { Samp1e } \\
\text { USW H-3 }\end{array}$ & $\begin{array}{c}\text { Sample } \\
\mathrm{J}-13\end{array}$ & $\begin{array}{l}\text { Sample } \\
\text { UE-25p 非1 }\end{array}$ \\
\hline \multicolumn{4}{|l|}{ THIS STUDY: } \\
\hline Solid phase: & uraninite & schoepite & rutherfordine \\
\hline $\begin{array}{l}\text { Solubility, } \\
\text { mol/L }\end{array}$ & $9.1 \times 10^{-8}$ & $1.98 \times 10^{-4}$ & $1.04 \times 10^{-3}$ \\
\hline$\underset{\%}{\text { Speciation, }}$ & 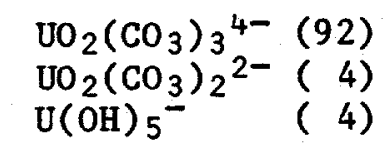 & $\begin{array}{l}\mathrm{UO}_{2}\left(\mathrm{CO}_{3}\right)_{2}{ }^{2-}(82) \\
\mathrm{UO}_{2} \mathrm{CO}_{3} \mathrm{O}^{4-}(14) \\
\mathrm{UO}_{2}\left(\mathrm{CO}_{3}\right)_{3}{ }^{-}(2)\end{array}$ & 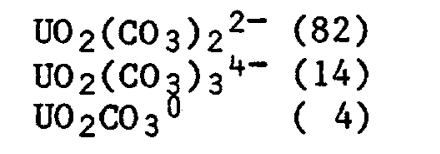 \\
\hline \multicolumn{4}{|l|}{ OGARD 1984: } \\
\hline Solid phase: & uraninite & schoepite & rutherfordine \\
\hline $\begin{array}{l}\text { Solubility, } \\
\text { mol/L }\end{array}$ & $4.05 \times 10^{-8}$ & $3.65 \times 10^{-3}$ & $1.74 \times 10^{-3}$ \\
\hline$\underset{\%}{\text { Speciation, }}$ & $\begin{array}{l}\mathrm{UO}_{2}\left(\mathrm{CO}_{3}\right)_{3}{ }^{4-} \\
\mathrm{U}(\mathrm{OH})_{5}\end{array}$ & $\begin{array}{c}\left(\mathrm{UO}_{2}\right)_{2} \mathrm{CO}_{3}(\mathrm{OH})_{3}-(98) \\
\left.\mathrm{UO}_{2}\left(\mathrm{CO}_{3}\right)_{2}\right)^{2-}\end{array}$ & $\begin{array}{cr}\mathrm{UO}_{2}\left(\mathrm{CO}_{3}\right)_{2}{ }^{2-} & (54) \\
\left(\mathrm{UO}_{2}\right)_{2} \mathrm{CO}_{3}(\mathrm{OH})_{3} & -(31) \\
\mathrm{UO}_{2}\left(\mathrm{CO}_{3}\right)_{3}{ }^{-} & (13) \\
\mathrm{UO}_{2} \mathrm{CO}_{3} \mathrm{O}^{0} & (2)\end{array}$ \\
\hline
\end{tabular}

aThe distribution of aqueous species for uranium listed in Ogard (1984) is incorrect. The correct distribution is listed above (KERRISK 1985). 
Table 6.3. Comparison of calculated strontium solubility/speciation

\begin{tabular}{|c|c|c|c|}
\hline & $\begin{array}{l}\text { Sample } \\
\text { USW H-3 }\end{array}$ & $\begin{array}{c}\text { Sample } \\
\mathrm{J}-13\end{array}$ & $\begin{array}{c}\text { Sample } \\
\text { UE-25p 非1 }\end{array}$ \\
\hline \multicolumn{4}{|l|}{ THIS STUDY: } \\
\hline Solid phase: & strontianite & strontianite & strontianite \\
\hline $\begin{array}{c}\text { Solubility, } \\
\text { mol/L }\end{array}$ & $2.13 \times 10^{-6}$ & $7.26 \times 10^{-4}$ & $4.03 \times 10^{-4}$ \\
\hline$\underset{\%}{\text { Speciation, }}$ & $\mathrm{Sr}^{2+}$ & $\mathrm{Sr}^{2+}$ & $\mathrm{Sr}^{2+}$ \\
\hline \multicolumn{4}{|l|}{ OGARD 1984: } \\
\hline Solid phase: & strontianite & strontianite & strontianite \\
\hline $\begin{array}{l}\text { Solubility, } \\
\text { mol/L }\end{array}$ & $3.28 \times 10^{-6}$ & $8.04 \times 10^{-4}$ & $5.27 \times 10^{-4}$ \\
\hline$\underset{\%}{\text { Speciation, }}$ & $\begin{array}{l}\mathrm{Sr}^{2+} \\
\mathrm{SrSO}_{4} 0 \quad(94) \\
(6)\end{array}$ & $\begin{array}{l}\mathrm{Sr}^{2+} \\
\mathrm{SrSO}_{4} \mathrm{O}^{\circ}(96)\end{array}$ & $\begin{array}{ll}\mathrm{Sr}^{2+} & (86) \\
\mathrm{SrSO}_{4} 0 & (14)\end{array}$ \\
\hline
\end{tabular}

\subsubsection{Americium}

The results of the comparative solubility/speciation calculations for americium are presented in Table 6.4. Our calculated solubilities for $\mathrm{Am}(\mathrm{OH}) \mathrm{CO}_{3}$ agree to within a factor of 10 with those of Ogard and Kerrisk (OGARD 1984) for each groundwater. For groundwaters USW H-3 and UE-25p 1 , we calculated $\mathrm{Am}(\mathrm{OH}) \mathrm{CO}_{3}$ to be the most stable phase. For groundwater $\mathrm{J}-13$, we calculated $\mathrm{AmO}_{2} \mathrm{OH}$, a phase that Kerrisk (1984b) does not include in the data base for the EQ3/6 calculations, to be more stable than $\mathrm{Am}(\mathrm{OH}) \mathrm{CO}_{3}$. The predicted total concentration of americium in equilibrium with $\mathrm{AmO}_{2} \mathrm{OH}$ in $\mathrm{J}-13$ groundwater would be several orders of magnitude lower than that calculated, assuming $\mathrm{Am}(\mathrm{OH}) \mathrm{CO}_{3}$ to be the controlling solid. An evaluation of the reliability of the data for this solid would seem to be appropriate. The same predominant aqueous species $\left(\mathrm{AmCO}_{3}{ }^{+}\right)$is predicted in our calculations as in those of Ogard and Kerrisk (OGARD 1984) for solutions $\mathrm{J}-13$ and $U \mathrm{E}-25 \mathrm{p}$ 非, although the percentages are quite different. However, the distribution of subordinate aqueous species is not in close agreement. For groundwater USW H-3, the dominant species of Ogard and Kerrisk (OGARD 1984), $\mathrm{Am}\left(\mathrm{CO}_{3}\right)_{2}^{-}$, is predicted to be of secondary importance in our calculations. These differences in the calculated distribution of species for all three groundwaters are indicative of differences in the thermodynamic data and suggest that the relatively close 
agreement in calculated solubilities (a factor of 10) may be fortuitous. Discrepancies such as these emphasize the need for a critical evaluation of the thermodynamic data for americium. In addition, experimental determination of key thermodynamic values, identified through sensitivity studies, needs to be initiated.

Table 6.4. Comparison of calculated americium solubility/speciation

\begin{tabular}{lcc}
\hline Sample & Sample & Sample \\
USW H-3 & $\mathrm{J}-13$ & UE-25p \#1 \\
\hline
\end{tabular}

\section{THIS STUDY:}

\begin{tabular}{|c|c|c|c|c|}
\hline Solid phase: & $\mathrm{Am}(\mathrm{OH}) \mathrm{CO}_{3}$ & $\mathrm{Am}(\mathrm{OH}) \mathrm{CO}_{3}$ & $\mathrm{Am}(\mathrm{OH}) \mathrm{CO}_{3}$ & \\
\hline $\begin{array}{l}\text { Solubility, } \\
\text { mol/L }\end{array}$ & $9.22 \times 10^{-11}$ & $1.51 \times 10^{-9}$ & $2.43 \times 10^{-}$ & \\
\hline$\underset{\%}{\text { Speciation, }}$ & $\begin{array}{l}\mathrm{Am}\left(\mathrm{CO}_{3}\right)_{3} 3^{3-}(68) \\
\mathrm{Am}\left(\mathrm{CO}_{3}\right)_{2}^{-}(29) \\
\mathrm{AmCO}_{3}{ }^{+}\end{array}$ & 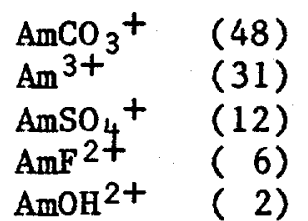 & $\begin{array}{l}\mathrm{AmCO}_{3}^{+} \\
\mathrm{AmSO}_{4}^{+} \\
\mathrm{Am}^{3+} \\
\mathrm{Am}\left(\mathrm{CO}_{3}\right)_{2}- \\
\mathrm{AmF}^{2+}\end{array}$ & $\begin{array}{l}(50) \\
(21) \\
(20) \\
\left(\begin{array}{l}4) \\
(4)\end{array}\right.\end{array}$ \\
\hline
\end{tabular}

OGARD 1984:

\begin{tabular}{|c|c|c|c|}
\hline Solid phase: & $\mathrm{Am}(\mathrm{OH}) \mathrm{CO}_{3}$ & $\mathrm{Am}(\mathrm{OH}) \mathrm{CO}_{3}$ & $\mathrm{Am}(\mathrm{OH}) \mathrm{CO}_{3}$ \\
\hline $\begin{array}{l}\text { Solubility, } \\
\mathrm{mol} / \mathrm{L}\end{array}$ & $6.85 \times 10^{-10}$ & $9.87 \times 10^{-9}$ & $2.16 \times 10^{-}$ \\
\hline$\underset{\%}{\text { Speciation, }}$ & $\begin{array}{ll}\mathrm{Am}\left(\mathrm{CO}_{3}\right)_{2} & (46) \\
\mathrm{Am}(\mathrm{OH})_{3} \mathrm{O}^{-} & (36) \\
\mathrm{AmOH} 2^{+} & (12) \\
\mathrm{AmCO}_{3}+ & (5)\end{array}$ & 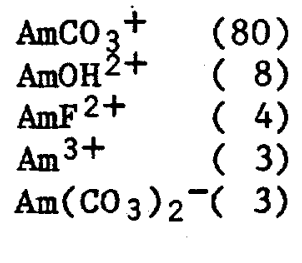 & $\begin{array}{l}\mathrm{AmCO}_{3}+ \\
\mathrm{Am}^{+}\left(\mathrm{CO}_{3}\right)_{2}^{-} \\
\mathrm{AmF}^{2+} \\
\mathrm{AmSO}_{4}^{+} \\
\mathrm{AmOH}^{2+} \\
\mathrm{Am}^{3+}\end{array}$ \\
\hline
\end{tabular}

\subsubsection{Plutonium}

The $\log (\mathrm{K})$ for the formation of $\mathrm{PuCO}_{3}{ }^{2+}$ was modified from the value compiled by Early et al. (EARLY 1982). The $\log (\mathrm{K})$ value of 40 used by Early et al. (EARLY 1982) has been discussed recently and is considered to be excessively large (RAI 1985). Rai and Ryan (RAI 1985) suggest that a more appropriate value would be between 12 and 15. Silva (1984) suggests that a maximum for the $\log (K)$ should be $\sim 13$. Therefore, a value of 
$\log (\mathrm{K})=13$ was adopted for our calculations. Kerrisk (WOLFSBERG 1982) states that a value of $\log (K)=9.9$ has been adopted for the data base $E Q 3 / 6$, although a revised value may have been used in the calculations of Ogard and Kerrisk (OGARD 1984). With these values of $\log (\mathrm{K}), \mathrm{PuCO}_{3}{ }^{2+}$ is not calculated to be an important species in any of the calculations.

Table 6.5 lists the results of the comparative solubility/speciation calculations for plutonium in groundwaters USW $\mathrm{H}-3$ and UE-25p非 1 . The agreement is excellent between our calculated solubilities and aqueous speciation and those of Ogard and Kerrisk (OGARD 1984). For both groundwaters, crystalline $\mathrm{PuO}_{2}$ is predicted to be more stable than $\mathrm{Pu}(\mathrm{OH})_{4}$ and would have a lower solubility. However, Ogard and Kerrisk (OGARD 1984) assume, probably correctly, that the more soluble hydrous oxide will be the controlling solid for plutonium.

Table 6.5. Comparison of calculated plutonium solubility/speciation in groundwater samples USW $\mathrm{H}-3$ and UE-25p \#1

\begin{tabular}{|c|c|c|}
\hline & $\begin{array}{l}\text { Sample } \\
\text { USW H-3 }\end{array}$ & $\begin{array}{l}\text { Sample } \\
\text { UE-25p \#1 } 1\end{array}$ \\
\hline \multicolumn{3}{|l|}{ THIS STUDY: } \\
\hline Solid phase: & $\mathrm{Pu}(\mathrm{OH})_{4}$ & $\mathrm{Pu}(\mathrm{OH})_{4}$ \\
\hline $\begin{array}{l}\text { Solubility, } \\
\text { mol/L }\end{array}$ & $1.69 \times 10^{-5}$ & $3.72 \times 10^{-8}$ \\
\hline$\underset{\%}{\text { Speciation, }}$ & $\mathrm{Pu}(\mathrm{OH})_{5}-(100)$ & $\begin{array}{l}\mathrm{Pu}(\mathrm{OH})_{5}-(95) \\
\mathrm{Pu}(\mathrm{OH})_{4}{ }^{-}(5)\end{array}$ \\
\hline \multicolumn{3}{|l|}{ OGARD 1984: } \\
\hline Solid phase: & $\mathrm{Pu}(\mathrm{OH})_{4}$ & $\mathrm{Pu}(\mathrm{OH})_{4}$ \\
\hline $\begin{array}{l}\text { Solubility, } \\
\text { mol/L }\end{array}$ & $1.33 \times 10^{-5}$ & $3.11 \times 10^{-8}$ \\
\hline$\underset{\%}{\text { Spectation, }}$ & $\mathrm{Pu}(\mathrm{OH})_{5}^{-}(100)$ & $\begin{array}{lr}\mathrm{Pu}(\mathrm{OH}) 5_{5}^{-} & (94) \\
\mathrm{Pu}(\mathrm{OH})_{4} \mathrm{O} & (6)\end{array}$ \\
\hline
\end{tabular}

Comparing the solubility/speciation of plutonium in groundwater J-13 is somewhat more complex. We obtained excellent agreement with the calculations of Ogard and Kerrisk (OGARD 1984) if all the $\mathrm{PuO}_{2}{ }^{2+}$ carbonate, hydroxide, and mixed carbonate-hydroxide complexes (EARLY 1982) were suppressed for our calculations using MINTEQ (see Table 6.6). Our calculated solubility for $\mathrm{Pu}(\mathrm{OH})_{4}$ is within a factor of 2 of that of Ogard and Kerrisk (OGARD 1984), and the aqueous speciation is in remarkable agreement. However, when the $\mathrm{PuO}_{2}{ }^{2+}$ carbonate, hydroxide, and mixed 
carbonate-hydroxide complexes (EARLY 1982) were included in our calculations, the agreement between our results and those of Ogard and Kerrisk (OGARD 1984) became less satisfactory (see Table 6.6). Our calculated solubility is 1000 times higher than that calculated by Ogard and Kerrisk (OGARD 1984), and the predicted distribution of aqueous species is entirely dissimilar. Discrepancies such as these emphasize (as did the americium analysis) the fact that significant efforts will have to be made to critically evaluate, validate, and improve thermodynamic data before geochemical calculations will be reliable enough for performance assessment calculations.

Table 6.6. Comparison of calculated plutonium solubility/speciation in groundwater $\mathrm{J}-13$.

\begin{tabular}{|c|c|c|c|c|c|}
\hline & \multicolumn{2}{|l|}{$J-13 a$} & \multicolumn{3}{|c|}{$J-13^{b}$} \\
\hline \multicolumn{6}{|l|}{ THIS STUDY: } \\
\hline Solld phase: & \multicolumn{3}{|l|}{$\mathrm{Pu}(\mathrm{OH})_{4}$} & \multicolumn{2}{|l|}{$\mathrm{Pu}(\mathrm{OH})_{4}$} \\
\hline $\begin{array}{l}\text { Solubility, } \\
\text { mol/L }\end{array}$ & \multicolumn{2}{|c|}{$2.34 \times 10^{-3}$} & & \multicolumn{2}{|l|}{$2.71 \times 10^{-6}$} \\
\hline \multirow[t]{2}{*}{$\underset{\%}{\text { Speciation, }}$} & \multicolumn{2}{|c|}{$\mathrm{PuO}_{2} \mathrm{CO}_{3} \mathrm{OH}^{-}(100)$} & & $\begin{array}{l}\mathrm{PuO}_{2}{ }^{+} \\
\mathrm{PuO}_{2} \mathrm{~F}_{3}^{-} \\
\mathrm{PuO}_{2} \mathrm{HCO}_{3}^{-} \\
\mathrm{PuO}_{2} \mathrm{~F}_{4}{ }^{-} \\
\mathrm{PuO}_{2} \mathrm{~F}_{2}{ }^{-}\end{array}$ & $\begin{array}{l}(52) \\
(33) \\
(8) \\
\left(\begin{array}{l}4 \\
( \\
(3)\end{array}\right.\end{array}$ \\
\hline & \multicolumn{3}{|c|}{$J-13 c$} & & \\
\hline \multicolumn{6}{|l|}{ OGARD (1984): } \\
\hline Solid phase: & \multicolumn{3}{|c|}{$\mathrm{Pu}(\mathrm{OH})_{4}$} & & \\
\hline $\begin{array}{l}\text { Solubility, } \\
\operatorname{mol} / \mathrm{L}\end{array}$ & \multicolumn{3}{|c|}{$1.79 \times 10^{-6}$} & & \\
\hline$\underset{\%}{\text { Speciation, }}$ & & $\begin{array}{l}\mathrm{PuO}_{2}{ }^{+} \\
\mathrm{PuO}_{2} \mathrm{~F}_{3}^{-} \\
\left.\mathrm{Pu}^{-} \mathrm{OH}_{5}\right)^{-} \\
\mathrm{PuO}_{2}\left(\mathrm{CO}_{3}\right)_{2}{ }^{2-} \\
\mathrm{PuO}_{2} \mathrm{~F}_{4} 2^{-}\end{array}$ & $\begin{array}{l}(71) \\
(20) \\
(3) \\
(2) \\
(2)\end{array}$ & & \\
\hline
\end{tabular}

aWith all aqueous species in MINTEQ data base considered.

bWith $\mathrm{PuO}_{2} 2+$ carbonate, hydroxide, and mixed carbonate-hydroxide complexes suppressed from consideration.

cogard (1984) apparently did not include $\mathrm{PuO}_{2}$ carbonate, hydroxide, and mixed carbonate-hydroxide complexes in their calculations. 
The calculations discussed above for the solubility/speciation of plutonfum in groundwater $\mathrm{J}-13$ were performed assuming an Eh value of $+700 \mathrm{mV}$ (see Sect. 6.2). Calculations with identical assumptions concerning the thermodynamic data for plutonium, but using an assigned Eh of $+800 \mathrm{mV}$ rather than $+700 \mathrm{mV}$, resulted in calculated solubilities being $\sim 1000$ times higher than those listed in Table 6.6. Apparently, the calculated solubility of $\mathrm{Pu}(\mathrm{OH})_{4}$ is quite sensitive to small differences in $\mathrm{Eh}$ under these pH-Eh conditions. Therefore, the solubility of plutonium must be considered highly uncertain until the precise redox conditions anticipated for the rock/water system relevant to J-13 groundwater can be determined and careful validation experiments to confirm the solubility estimates for plutonium can be accomplished.

\subsection{DISCUSSION}

The calculated solubility/speciation for several radionuclides reported by Ogard and Kerrisk (OGARD 1984) appears to be reasonable for the assumptions and thermodynamic data used. Our calculations confirm, in general, the results of Ogard and Kerrisk (OGARD 1984). However, agreement between the two sets of geochemical calculations does little more than verify that the two computer codes used in the separate analyses solve thermodynamic relationships correctly and that the thermodynamic data are not entirely inconsistent. Significant uncertainty remains in using calculated solubility/ speciation results as a source term in performance assessment calculations. It would be desirable to perform sensitivity calculations to determine what effect, if any, uncertainties in analytical concentrations of elements and related parameters such as $\mathrm{pH}$ and Eh would have on the calculated solubility/speciation of radionuclides. Calculated solubilities must be confirmed experimenta1ly to provide reasonable assurance that nonconservative assump-: tions are avoided. Some of the limitations associated with such calculations include: (1) the assumption of equilibrium, (2) missing or invalid thermodynamic data, (3) incomplete accounting for all relevant and important geochemical processes, and (4) lack of experimental validation of calculated results. These limitations are discussed in more detail in NRC (1984) and Jacobs and Whatley (JACOBS 1985). 
7. ACKNOWLEDGMENTS

The authors wish to acknowledge the excellent laboratory technical work performed by F. I. Case and G. C. Young, the secretarlal effort of R. E. Keever, and the editorial assistance of D. R. Reichle in the preparation of this document. 


\section{REFERENCES}

BARNEY 1983. G. S. Barney, Radionuclide Sorption Kinetics and Column Sorption Studies with Columbia River Basalts, SD-BWI-TI-168, Rockwel1 Hanford Operations, Richland, Wash., 1983.

BISH 1982. D. L. Bish, D. T. Vaniman, F. M. Byers, Jr., and D. E. Broxton, Summary of Mineralogy-Petrology of Tuffs of Yucca Mountain and the Secondary-Phase Thermal Stability in Tuffs, LA-9321-MS, Los Alamos National Laboratory, Los Alamos, New Mexico, 1982.

BLENCOE 1985. J. G. Blencoe, Review and Assessment of Radionuclide Solubility Information for the Hanford, Washington, Candidate HLW Repository Site, Oak Ridge National Laboratory, Oak Ridge, Tenn., in preparation.

BRYANT 1984. E. A. Bryant and D. T. Vaniman, Research and Development Related to the Nevada Nuclear Waste Storage Investigations: July 1September 30, 1983, LA-10006-PR, Los Alamos National Laboratory, Los Alamos, New Mexico, 1984.

DANIELS 1982. W. R. Daniels et al., Summary Report on the Geochemistry of Yucca Mountain and Environs, LA-9328-MS, Los Alamos National Laboratory, Los Alamos, New Mexico, 1982.

DOE 1984a. Draft Environmenta1 Assessment; Yucca Mountain Site, Nevada. Research and Development Area, Nevada, DOE/RL-0012, Department of Energy, Washington, D.C., 1984.

DOE 1984b. Draft Environmental Assessment, Reference Repository Location, Hanford Site, Washington, DOE/RL-0017, Department of Energy, Washington, D.C., 1984 .

EARLY 1982. T. O. Early, D. R. Drewes, G. K. Jacobs, and R. C. Routson, Geochemical Controls on Radionuclide Releases from a Nuclear Waste Repository in Basalt: Estimated Solubilities for Selected Elements, RHO-BW-ST-39P, Rockwell Hanford Operations, Richland, Wash., 1982 .

EARLY 1984. T. O. Early, G. K. Jacobs, and D. R. Drewes, "Geochemical Controls on Radionuclide Releases from a Nuclear Waste Repository in Basalt: Estimated Solubilities of Selected Elements," in Geochemical Behavior of Disposed Radioactive Wastes, eds., G. S. Barney, J. D. Navratil, W. W. Schulz, ACS Symp. Ser. 246, 1984 .

FELMY 1984. A. R. Felmy, D. C. Girvin, and E. A. Jenne, MINTEQ: A Computer Program for Calculating Aqueous Geochemical Equilibria, EPA-600/3-84-032 (NTIS PB84-157148), Prepared for the U.S. Environmenta1 Protection Agency (Athens, Georgia) by Battelle Pacific Northwest Laboratory, Richland, Wash., 1984. 
JACOBS 1985. G. K. Jacobs and S. K. Whatley, Proceedings of a Conference on the Application of Geochemical Models to High-Level Nuclear Waste

Repository Assessment, NUREG/CP-0062, ORNL/TM-9585; Oak Ridge National Laboratory, Oak Ridge, Tenn., 1985.

KELMERS 1984a. A. D. Kelmers, R. J. Clark, N. H. Cutshall, G. K. Jacobs, J. S. Johnson, J. H. Kessler, and R. E. Meyer, Evaluation of Radionuclide Geochemical Information Developed by DOE High-Level Nuclear Waste Repository Projects; Annual Progress Report for the Period October 1982 - September 1983, NUREG/CR-3730, ORNL/TM-9109, Oak Ridge National Laboratory, Oak Ridge, $\overline{\text { Tenn }}, 1984$.

KELMERS 1984b. A. D. Kelmers, J. H. Kessler, W. D. Arnold, R. E. Meyer, N. H. Cutsha11, G. K. Jacobs, S. Y. Lee, Progress in the Evaluation of Radionuclide Geochemical Information Developed by DOE High-Level Nuclear Waste Repository Site Projects: Report for October-December 1983, NUREG/CR-3851, Vo1. 1, ORNL/TM-9191/V1, Oak Ridge National Laboratory, Oak Ridge, Tenn., 1984.

KELMERS 1984c. A. D. Kelmers, J. H. Kessler, W. D. Arnold, R. E. Meyer, N. H. Cutsha11, G. K. Jacobs, S. Y. Lee, R. J. Clark, Progress in Evaluation of Radionuclide Geochemical Information Developed by DOE High-Level Nuclear Waste Repository Site Projects: Report for January-March 1984, NUREG/CR-3851, Vo1. 2, ORNL/TM-9191/V2, Oak Ridge Nationa1 Laboratory, Oak Ridge, Tenn., 1984.

KELMERS 1984d. A. D. Kelmers, Review and Assessment of Radionuclide Sorption Information for the Basalt Waste Isolation Project Site (1979 Through May 1983), Oak Ridge National Laboratory, Oak Ridge, Tenn., 1984.

KELMERS 1985a. A. D. Kelmers, J. H. Kessler, F. G. Seeley, W. D. Arnold, R. E. Meyer, F. J. Smith, N. H. Cutshall, G. K. Jacobs, and S. Y. Lee, Evaluation of Radionuclide Information Developed by DOE High-Level Nuclear Waste Repository Site Projects: Annual Progress Report for October 1983 September 1984, NUREG/CR-4136, ORNL/TM-9526, Oak Ridge National Laboratory, Oak Ridge, Tenn., 1985.

KELMERS 1985b. A. D. Kelmers, F. G. Seeley, W. D. Arno1d, R. E. Meyer, G. K. Jacobs, and S. K. What ley, Progress in Evaluation of Radionuclide Geochemical Information Developed by DOE High-Level Nuclear Waste Repository Site Projects; Report for October - December 1984, NUREG/CR-4236, ORNL/TM-9614/V1, Oak Ridge National Laboratory, Oak Ridge, Tenn., 1985.

KELMERS 1985c. A. D. Kelmers, W. D. Arnold, R. E. Meyer, F. J. Smith, G. K. Jacobs, S. Y. Lee, Progress in Evaluation of Radionuclide Geochemical Information Developed by DOE High-Level Nuclear Waste Repository Site Projects: Report for April - June 1984, NUREG/CR3851, Vo1. 3, ORNL/TM-9191/V3, Oak Ridge National Laboratory, Oak Ridge, Tenn., 1985.

KERRISK 1983. J. F. Kerrisk, Reaction-Path Calculations of Groundwater Chemistry and Mineral Formation at Rainier Mesa, Nevada, LA-9912-MS, Los Alamos National Laboratory, Los Alamos, New Mexico, 1983. 
KERRISK 1984a. J. F. Kerrisk, Solubility Limits on Radionuclide Dissolution at a Yucca Mountain Repository, LA-9995-MS, Los Alamos National Laboratory, Los Alamos, New Mexico, 1984.

KERRISK 1984b. J. F. Kerrisk, Americium Thermodynamic Data for the EQ3/6 Database, LA-10040-MS, Los Alamos National Laboratory, Los Alamos, New Mexico, 1984.

KERRISK 1985. J. F. Kerrisk, Los Alamos National Laboratory, Los Alamos, New Mexico, personal communication, 1985.

KRUPKA 1983. K. M. Krupka, E. A. Jenne, and W. J. Deutsch, Validation of the WATEQ4 Geochemical Mode1 for Uranium, PNL-4333, Pacific Northwest Laboratory, Richland, Wash., 1983.

LANE 1984. D. L. Lane, T. E. Jones, and M. H. West, "Preliminary Assessment of Oxygen Consumption and Redox Conditions in a Disposed Nuclear Waste Repository in Basalt," in Geochemical Behavior of Disposed Radioactive Waste, ACS Symp. Ser. 246, eds., G. S. Barney, J. D. Navrat11, W. W. Schultz, ACS Symp. Ser. 246, 1984.

MEYER 1983. R. E. Meyer, W. D. Arnold, F. I. Case, S. Y. Shiao, and D. A. Palmer, Valence Effects on Absorption: A Preliminary Assessment of the Effects of Valence State Control on Sorption Measurements, NUREG-2863, ORNL-5905, Oak Ridge National Laboratory, Oak Ridge, Tenn., 1983.

MEYER 1984. R. E. Meyer, W. D. Arnold, and F. I. Case, Valence Effects on the Sorption of Nuclides on Rocks and Minerals, NUREG/CR-3389, ORNL-5978, Oak Ridge National Laboratory, Oak Ridge, Tenn., 1984.

MEYER 1985a. "R. E. Meyer, W. D. Arnold, and F. I. Case, Valence Effects on the Sorption of Nuclides on Rocks and Minerals. II, NUREG/CR-4114, ORNL-6137, Oak Ridge National Laboratory, Oak Ridge, Tenn., 1985.

MEYER 1985b. R. E. Meyer, private communication.

NRC 1984. U.S. Nuclear Regulatory Commission, Determination of Radionuclide Solubility in Groundwater for Assessment of High-Level Waste Isolation, Technical Position Paper, U.S. Nuclear Regulatory Commission, Washington, D.C., 1984 .

OGARD 1983. A. E. Ogard, K. Wolfsberg, and D. T. Vaniman, Research and Development Related to the Nevada Nuclear Waste Storage Investigations: Apr11 1-June 30, 1983. LA-9846-PR, Los Alamos National Laboratory, Los Alamos, New Mexico, 1983.

OGARD 1984. A. E. Ogard and J. F. Kerrisk, Groundwater Chemistry Along Flow Paths Between a Proposed Repository Site and the Accessible Environment, LA-10188-MS, Los Alamos National Laboratory, Los Alamos, New Mexico, 1984 .

RAI 1985. D. Rai and J. L. Ryan, "Neptunium(IV) Hydrous Oxide Solubility under Reducing Conditions and Carbonate Conditions," Inorg. Chem. 24, 247-51 (1985). 


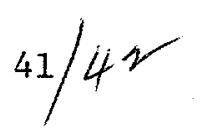

SALTER 1981. P. F. Salter, L. L. Ames, and J. E. McGarrah, The Sorption Behavior of Selected Radionuclides on Columbia River Basalts, RHO-BWI-LD-48, Rockwel1 Hanford Operations, Richland, Wash., 1981.

SALTER 1983. P. F. Salter and G. K. Jacobs, BWIP Data Package for Reference Solubility Kd Values, SD-BWI-DP-001, Rockwell Hanford Operations, Richland, Wash., 1983.

SCR 1982. Site Characterization Report for the Basalt Waste Isolation Project, DOE/RL-82-3, Department of Energy, Washington, D.C., 1982 .

SILVA 1984. R. J. Silva, Lawrence Berkeley Laboratory, Berkeley, Calif., personal communication, 1984 .

SOO 1984. P. Soo, Review of Waste Package Verification Tests. Semiannual Report April - September 1983, Vo1. 3, NUREG/CR-3091, Vol. 3, Brookhaven National Laboratory, Upton, New York, 1984.

VANIMAN 1984. D. Vaniman et al., Variations in Authigenic Mineralogy and Sorptive Zeolite Abundance at Yucca Mountain, Nevada, Based on Studies of Dri11 Cores USWGU-3 and G-3, LA-9707-MS, Los Alamos National Laboratory, Los Alamos, New Mexico, 1984.

WOLFSBERG 1982. K. Wolfsberg, W. R. Daniels, B. R. Erda1, and D. T. Vaniman, Research and Development Related to the Nevada Nuclear Waste Storage Investigations; Apri1 1-June 30, 1982, LA-9484-PR, Los Alamos National Laboratory, Los Alamos, New Mexico, 1982.

WOLFSBERG 1984. K. Wolfsberg and D. T. Vaniman, Research and Development Related to the Nevada Nuclear Waste Storage Investigations: October 1December 31, 1983, LA-0032-PR, Los Alamos National Laboratory, Los Alamos, New Mexico, 1984. 
NUREG/CR-4236, Vo1. 2

ORNL/TM-9614/V2

Dist. Category RW

\section{INTERIM DISTRIBUTION}

1. W. D. Arnold

2. J. T. Bell

3. J. G. Blencoe

4. R. 0. Chester

5. N. H. Cutshall

6. L. M. Ferris

7. R. M. Gove

8. J. R. Hightower

9. G. K. Jacobs

10. A. D. Kelmers

11. D. C. Kocher

12. S. Y. Lee

13. A. P. Malinauskas

14. R. E. Meyer

15. D. R. Reichle

16. S. K. Whatley

17. R. G. Wymer

18-19. Technical Information Center

20. Office of Assistant Manager, Energy Research and Development, Department of Energy, Oak Ridge Operations Office, Oak Ridge, TN

21. Laboratory Records - RC 


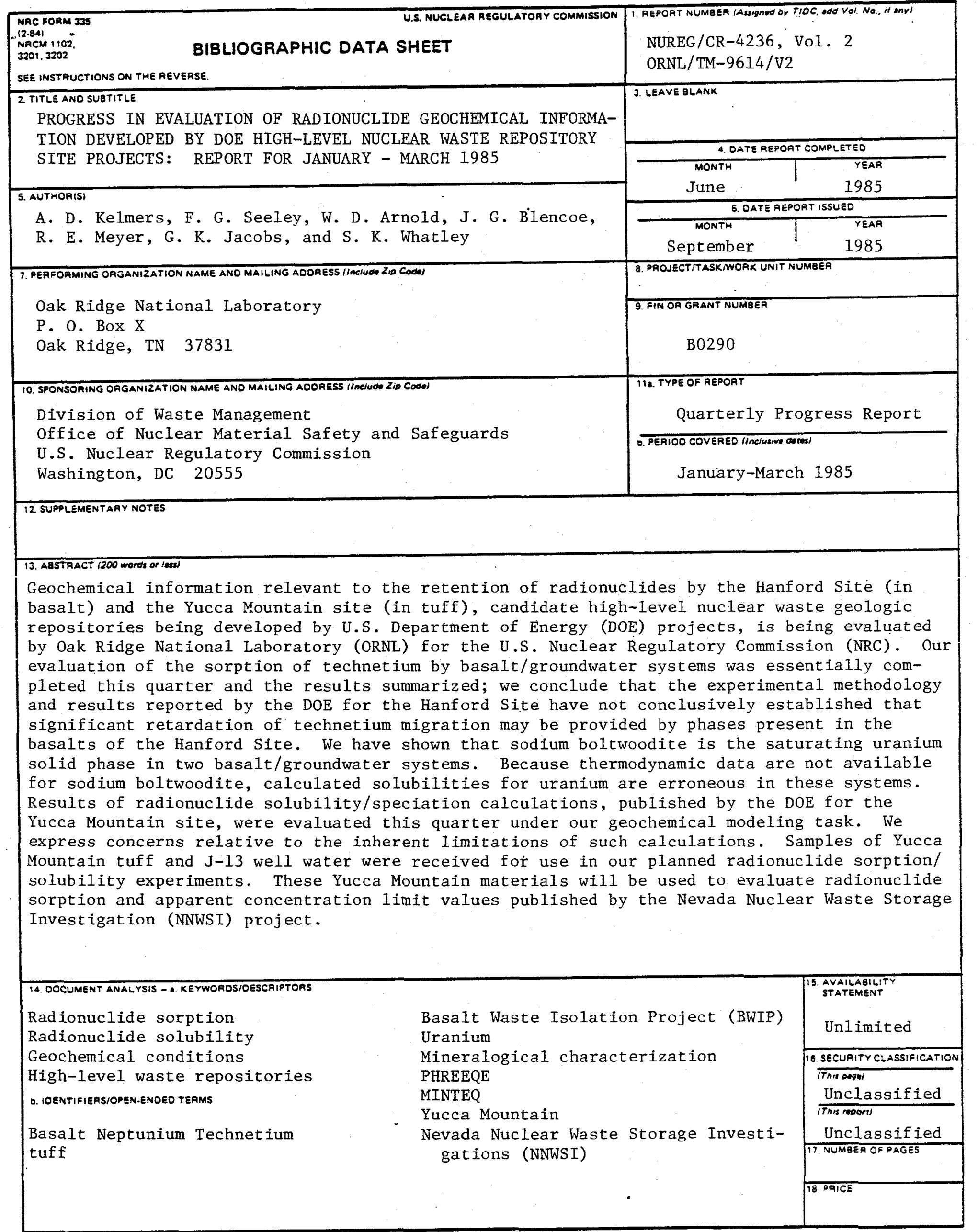

